\title{
Educators' Perceptions of Collaborative Planning Processes for Students with Disabilities
}

Nari Carter

Brigham Young University - Provo

Follow this and additional works at: https://scholarsarchive.byu.edu/etd

Part of the Counseling Psychology Commons, and the Special Education and Teaching Commons

\section{BYU ScholarsArchive Citation}

Carter, Nari, "Educators' Perceptions of Collaborative Planning Processes for Students with Disabilities" (2006). Theses and Dissertations. 449.

https://scholarsarchive.byu.edu/etd/449

This Thesis is brought to you for free and open access by BYU ScholarsArchive. It has been accepted for inclusion in Theses and Dissertations by an authorized administrator of BYU ScholarsArchive. For more information, please contact scholarsarchive@byu.edu, ellen_amatangelo@byu.edu. 


\title{
EDUCATORS' PERCEPTIONS OF COLLABORATIVE PLANNING PROCESSES FOR STUDENTS WITH DISABILITIES
}

\author{
By \\ Nari J. Carter \\ A thesis submitted to the faculty of \\ Brigham Young University \\ In partial fulfillment of the requirements for the degree of
}

Master of Science

Department of Counseling Psychology and Special Education

Brigham Young University

August, 2006 
Copyright (C) 2006 Nari J. Carter All Rights Reserved 


\title{
BRIGHAM YOUNG UNIVERSITY
}

\section{GRADUATE COMMITTEE APPROVAL}

\author{
of a thesis submitted by
}

\author{
Nari J. Carter
}

This thesis has been read by each member of the following graduate committee and by majority vote has been found to be satisfactory.

Date

Date

Date
Mary Anne Prater, Chair

Aaron Jackson

Michelle Marchant 


\section{BRIGHAM YOUNG UNIVERSITY}

As chair of the candidate's graduate committee, I have read the thesis of Nari J. Carter in its final form and have found that (1) its format, citations, and bibliographical style are consistent and acceptable and fulfill university and department style requirements; (2) its illustrative materials including figures, tables, and charts are in place; and (3) the final manuscript is satisfactory to the graduate committee and is ready for submission to the university library.

Date

Accepted for the Department
Mary Anne Prater

Chair, Graduate Committee
Tina T. Dyches

Graduate Coordinator

Accepted for the College

K. Richard Young

Dean, McKay School of Education 


\begin{abstract}
EDUCATORS' PERCEPTIONS OF COLLABORATIVE PLANNING PROCESSES

FOR STUDENTS WITH DISABILITIES
\end{abstract}

\author{
Nari J. Carter \\ Department of Special Education \\ Master of Science
}

When students with disabilities are included in general education classes, collaboration between special and general education teachers is necessary to ensure that the students have access to the general education curriculum and also have supports that enable them to benefit from their education. This paper reports the results of a phenomenological study that investigated the nature of a collaborative planning experience for pairs of special and general education teachers. From the teachers' descriptions of their experience, sharing common philosophies about educating students with disabilities was an important aspect of successful collaborative planning. Collaboration in this experience was voluntary and was defined by teachers contributing professional expertise, defining problems to address, and expressing commitment to solve or address the identified problems. 


\section{ACKNOWLEDGMENTS}

As I review this completed projected, I realize that this project reflects the knowledge, expertise, and contributions of many individuals. Before I could conduct and complete this project I had to learn about research. While completing my coursework for my master's degree, faculty at Brigham Young University taught me how to plan and conduct research. I am grateful for their experience and for their skill in conveying knowledge to their students.

As my teachers guided me through the process of narrowing and selecting a research topic, my committee chair, Dr. Mary Anne Prater was incredibly patient and supportive as I wrote proposals and then changed my mind about possible projects. Dr. Prater allowed me the freedom to find and select a topic of personal interest. She supported me through the process of obtaining university approval of my project, and she coached and directed me through the completion of my project. Thank you Dr. Prater. Thank you for the time you expended on this project, and thank you for allowing me to use your work in my project. You have been a wonderful coach, mentor, and friend.

Drs. Aaron Jackson and Michelle Marchant served on my thesis committee. They too provided support and encouragement as I completed my project. Thank you Dr. Marchant, for being a friend and teacher. I appreciate all you have taught me about 
research. Thank you Dr. Jackson for being willing to serve on my committee. As a novice qualitative researcher, I greatly appreciated your support, and learned from my interactions with you.

I couldn't have completed this project without the support of my family. The project has become something of a family effort. My husband supported all of my efforts to complete this project--even taking time to review my data analysis processes. My daughter Leah networked with her professors, and arranged for me to consult with Dr. Glenn Christensen of the Marriott School of Management. Thank you Leah, and thank you Dr. Christensen for taking time to teach me about qualitative research. My son Ryan, and my daughter Elise were patient and supportive as I spent hours working on this project. My parents expressed confidence in my ability to complete a thesis project, and they encouraged me throughout the project. Thank you to my sister Marla, for being willing to recruit teachers for me, and for your contributions to the project. 


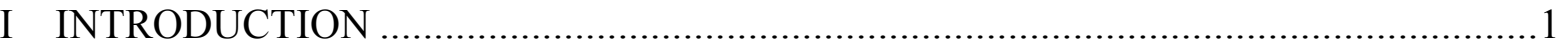

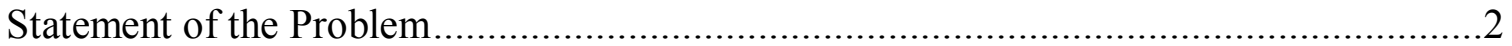

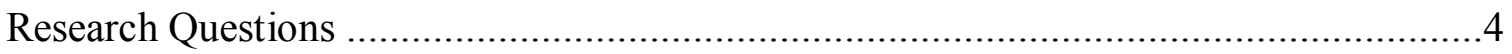

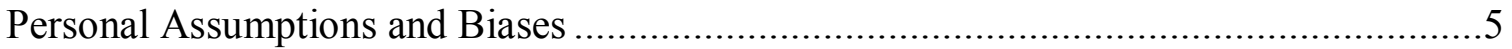

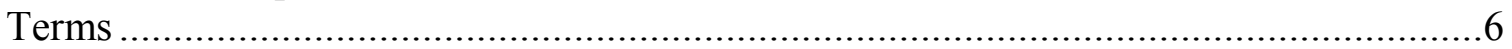

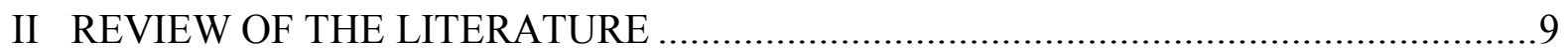

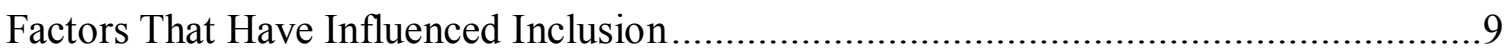

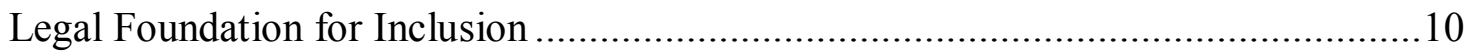

Societal and Philosophical Influence .................................................................. 14

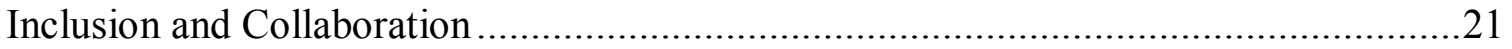

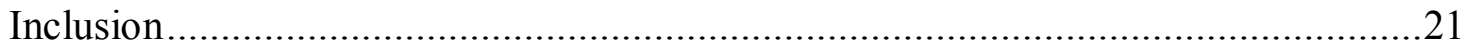

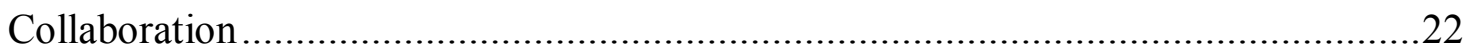

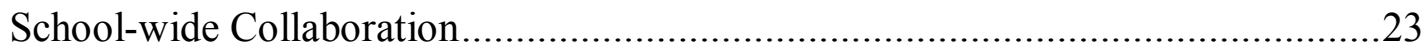

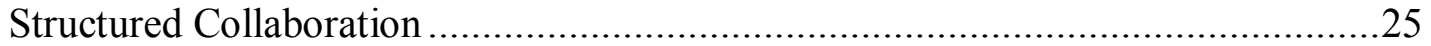

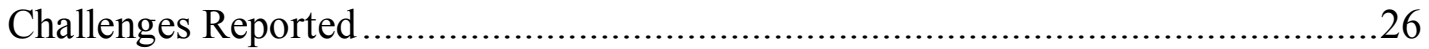

Adaptive Instruction and Accommodations .....................................................29

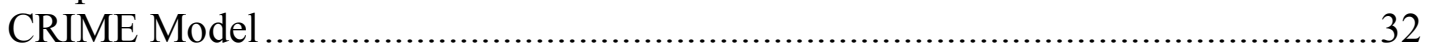

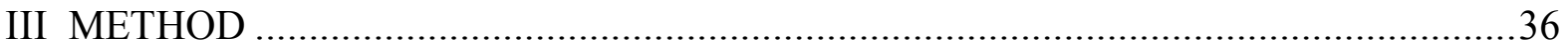

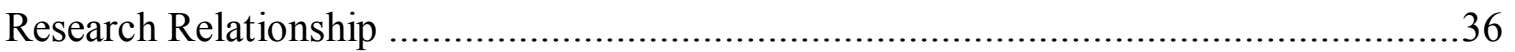

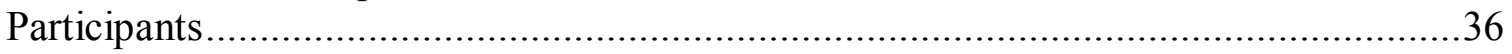

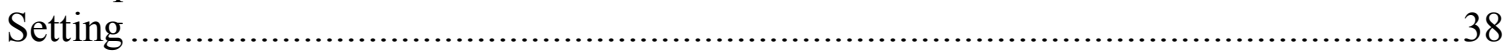

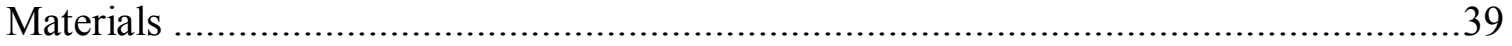

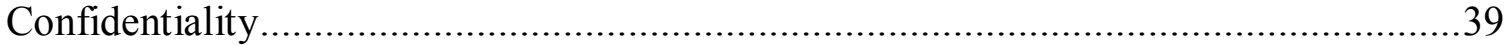

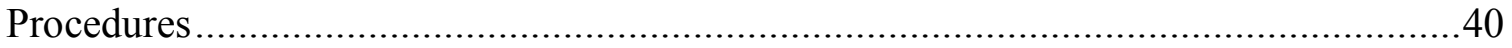

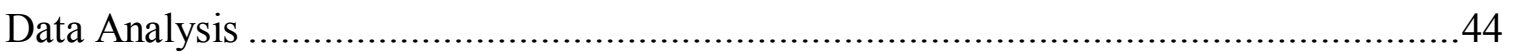

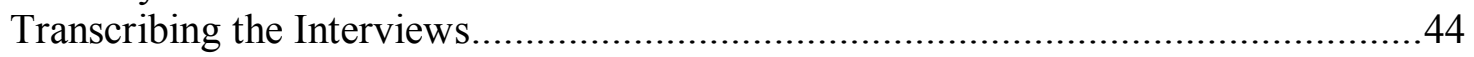

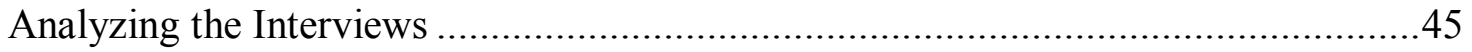

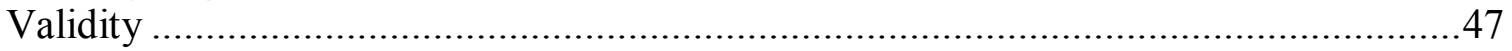

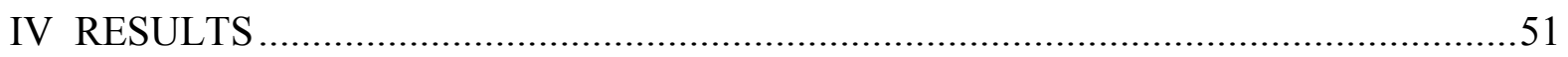

Structure of the CRIME Collaboration Experience ………..........................................51

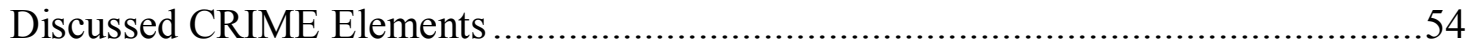

Reached Consensus and Encountered Differences.................................................56

Described Philosophical Perspectives ...................................................................59

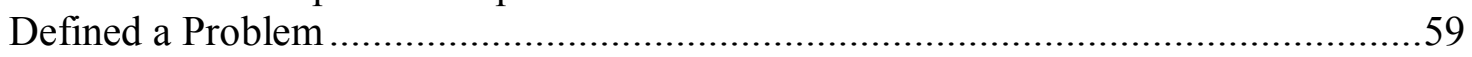

Planned Accommodations and Adaptations........................................................67

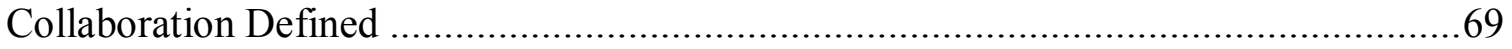

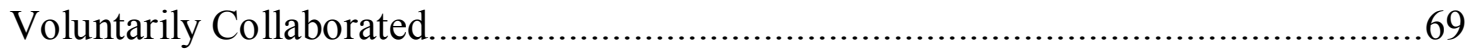




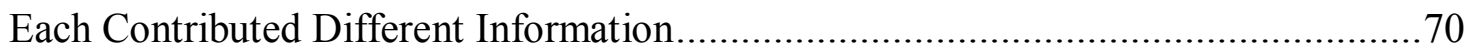

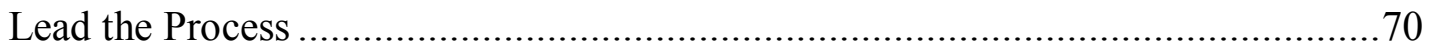

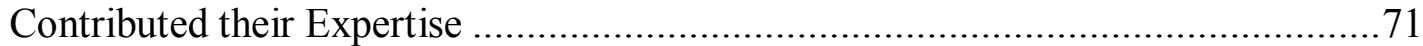

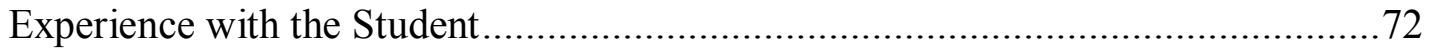

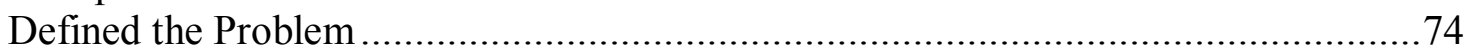

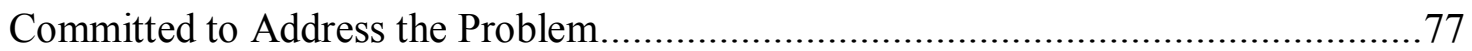

Teachers' Perceptions of the CRIME Process ...............................................................

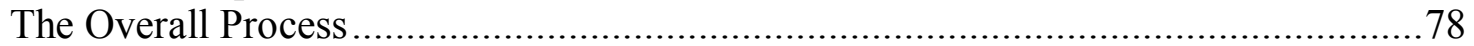

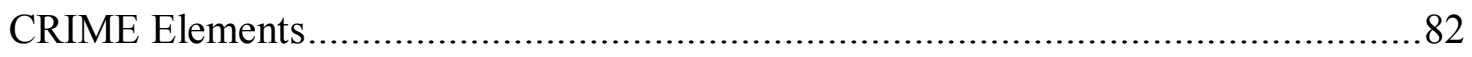

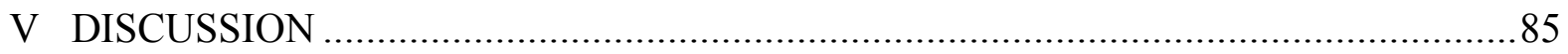

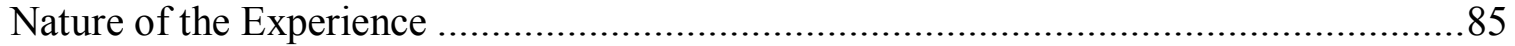

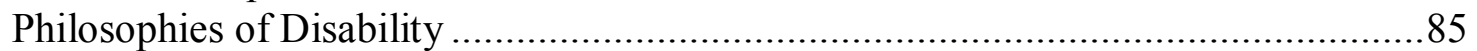

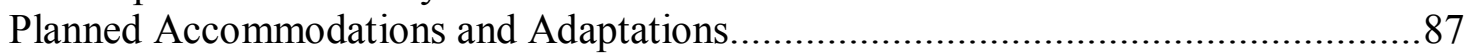

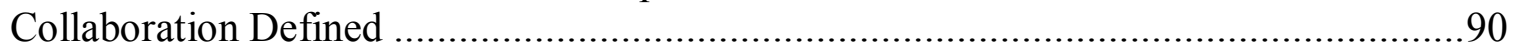

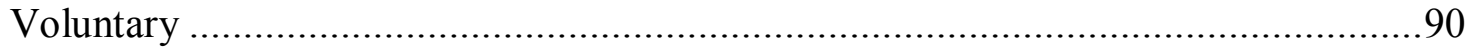

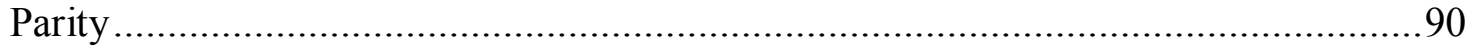

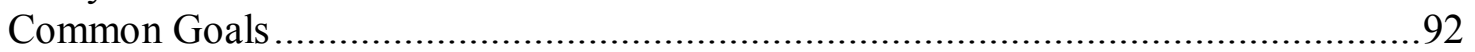

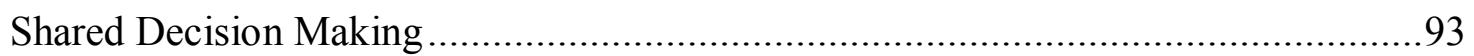

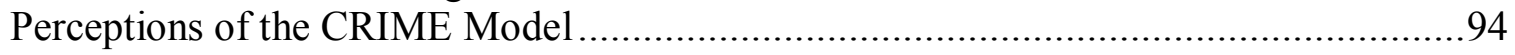

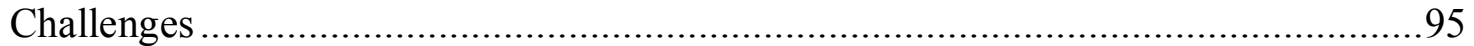

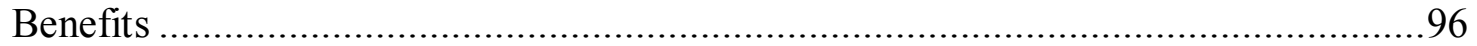

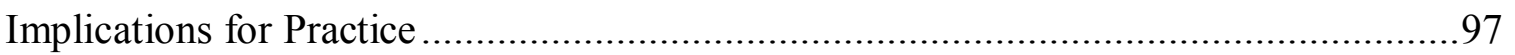

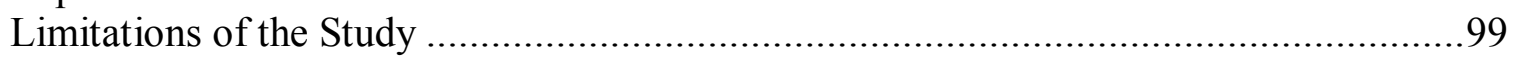

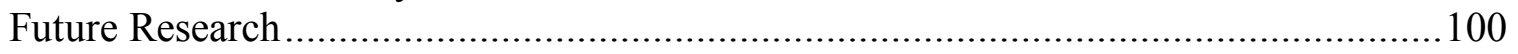

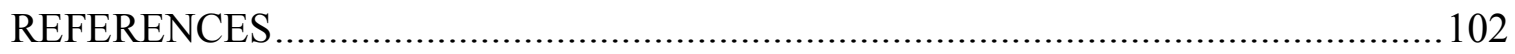

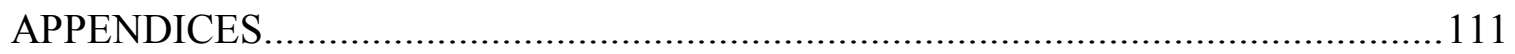

Appendix A: Personal Experience Memo …………................................................111

Appendix B: Consent to be a Research Participant.....................................................113

Appendix C: Confidential Demographic Questionnaire............................................115

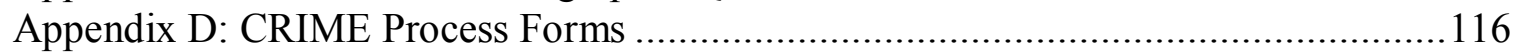

Appendix E: Sample Transcription ......................................................................

Appendix F: Coding Categories--CRIME, Process, and Evaluation ............................121

Appendix G: CRIME Category Condensed Statements ............................................122

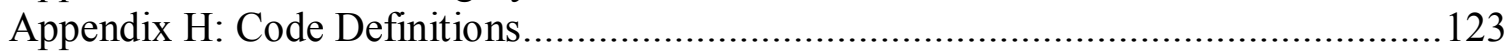

Appendix I: General Education Teacher--Pair 5 Coded Interview ...............................128

Appendix J: Collaboration Experience and Collaboration Defined ................................129

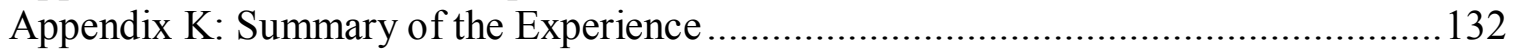

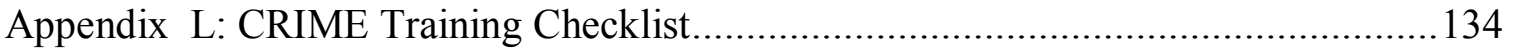

Appendix M: Teachers' Comments About Their Students ..........................................135 


\section{LIST OF TABLES}

$\begin{array}{ll}\text { TABLE } & \text { PAGE }\end{array}$

1 Examples of Classroom Accommodations and Adaptations .................................34

2 Teacher Demographics .......................................................................... 37

3 Philosophical Perspectives of Disability or of Instructing Students.......................60 with Disabilities

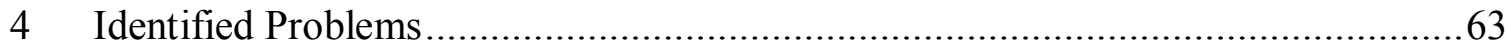

5 Planned Accommodations and Adaptations....................................................6. 67

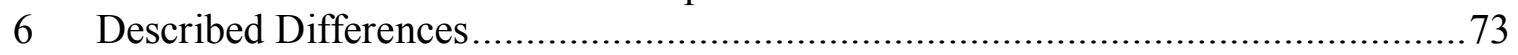




\section{LIST OF FIGURES}

$\begin{array}{ll}\text { FIGURE } & \text { PAGE }\end{array}$

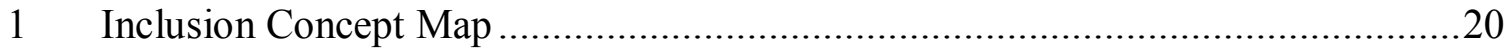

2 Structure of the Collaboration Experience .......................................................53 


\section{CHAPTER I}

\section{INTRODUCTION}

For most of the $20^{\text {th }}$ century, federal laws did not protect the educational interests of students with disabilities. In fact, students with disabilities were often excluded from educational opportunities afforded their nondisabled peers (Rothstein, 2000). It was not until after 1971, when the Supreme Court ruled that students with disabilities were denied constitutional protections of due process and equal protection in Pennsylvania Association for Retarded Children (PARC) v. Pennsylvania (1971) and Mills v. Board of Education (1972), that congress passed laws to protect the educational interests of students with disabilities. The Education of All Handicapped Children Act (EAHCA), passed in 1975, was the first law that outlined educational procedures and protections for students with disabilities. Specifically, the law mandated that students with disabilities have access to free and appropriate public education (FAPE), an individualized education program (IEP), protection from discrimination with procedural safeguards, parental involvement in education decisions, and education in the least restrictive environments.

The EAHCA (1975) shifted educational practices for students with disabilities from exclusionary practices to inclusionary practices, and brought them into general education classrooms. As larger numbers of students with disabilities began to be educated in general education classrooms, defining FAPE for such students became an issue, and was defined by the Supreme Court. In 1982, in the Board of Education v. Rowley case, the Supreme Court defined appropriate education for students with disabilities as education that: 
Consists of access to specialized instruction and related services which are individually designed to provide educational benefit to the handicapped child. . . Insofar as a State is required to provide a handicapped child with a 'free appropriate public education,' we hold that it satisfied this requirement by providing personalized instruction with sufficient support services to permit the child to benefit educationally from that instruction. . . In addition, the IEP, and therefore the personalized instruction, should be formulated in accordance with the requirements of the Act and, if the child being educated in the regular classrooms of the public education system, should be reasonably calculated to enable the child to achieve passing marks and advance from grade to grade. (Rowley, 1982, section III A)

The court emphasized that supportive services may be required to enable students with disabilities to benefit from specialized instruction. Not only may related services be necessary to provide opportunity for students with disabilities to benefit from their education, schools are also required to provide a full array of supplemental aides and supports for students with disabilities who are included in general education classes before they can consider moving them into more restrictive environments (Oberti, 1993).

\section{Statement of the Problem}

Laws and court rulings require schools to include students with disabilities in general education classes to the maximum extent possible, while at the same time, providing them with support necessary to enable them to benefit from their education. Effective inclusion that meets both of these objectives is more likely to occur in schools that promote and encourage collaboration between special education and general 
education teachers. The reason collaboration between special education and general education teachers is needed is students with disabilities should have access to the general education curriculum and instruction that is individualized to enable the students to benefit from instruction. Typically, special education teachers are trained to know how to adapt instruction to meet the educational needs of students with disabilities, and general education teachers are trained to teach students grade level curriculum. Collaboration between these two groups of professionals enables teachers to utilize their expertise to plan appropriate education for students with disabilities included in general education classes. A number of research studies have indicated that when collaboration between special education and general education teachers occurs, is structured (specific procedures and models are used to guide collaborative interactions), and is supported by school administration, educational outcomes for students with disabilities improve (Amato, 1996; Burnstein, Sears, Wilcoxen, Cabello, \& Spagna, 2004; Hunt, Soto, Maier, \& Doering, 2003; Marston, 1996).

Unfortunately, not all schools support and promote collaboration, and general education teachers have reported challenges related to including students with disabilities in their classes. Among the problems teachers have reported are they lack training to know how to adapt instruction for students with disabilities, they do not have enough time for collaboration, and they lack support for collaboration from their school administration (Edmunds, 2000; Heflin \& Bullock, 1999; Kamens, Loprete, \& Slostad; 2003; Scruggs \& Mastropieri, 1996; Stockall \& Garten, 2002; Zigmond \& Baker, 1996). When general education and special education teachers do not coordinate efforts to plan adaptive instruction for students with disabilities, the students with disabilities may not 
receive adaptive instruction in general education classrooms, which can significantly impact their academic progress. Stockall and Gartin (2002) reported that inclusion in some schools can mean physical inclusion and not academic inclusion; and Zigmond and Baker (1996) observed that teachers in inclusive classrooms did not provide students with disabilities adaptive education designed to improve academic skills.

Collaboration then is a critical component of effective inclusion. Although research has shown that when schools implement school-wide collaboration models in inclusive settings, students with disabilities can benefit, research studies have not investigated whether collaboration models designed to be used by individual teachers can provide structure necessary for effective collaborative planning. The Curriculum, Rules Instruction, Materials, and Environment (CRIME) collaboration model (Prater, 2003) was designed to promote collaboration between special and general education teachers, and to focus teachers' efforts in planning educational accommodations and adaptations for students with disabilities. The model's name is based on an acronym representing critical elements of a classroom (curriculum, rules, instruction, materials, and environment). Specifically, the CRIME model provides a framework for special and general education teachers to compare a general education classroom environment to a student's learning profile, and to then use that information to plan appropriate accommodations and adaptations for the student with disabilities included in the general education class.

\section{Research Questions}

The CRIME model has not been evaluated in research studies and the purpose of this research was to determine if this model was perceived as useful and effective in facilitating collaborative planning between special and general education teachers. This 
research project was a qualitative research study that addressed the questions listed below.

- When teachers use the CRIME model to collaboratively plan instructional supports for students with disabilities, what is the nature of the experience?

- How is collaboration defined in the experience?

- What are special and general education teachers' perceptions of the CRIME model?

\section{Personal Assumptions and Biases}

Maxwell (2005) suggested that prior to conducting qualitative research a researcher should examine his/her motives and purposes for conducting the research by writing a personal experience memo. Excerpts from this researcher's personal experience memo are included in Appendix A and are summarized below. Although these statements reflect this researcher's personal biases and assumptions, they were set aside as the researcher analyzed the data associated with this project.

- Children with disabilities can learn.

- Like other children, children with disabilities have strengths.

- Inclusion with appropriate support is preferable for students with mild/moderate disabilities.

- Collaboration is essential for general education teachers to learn strategies for instructing students with disabilities.

- Teachers would benefit from using a structured framework for collaborative planning. 
- Teachers can and should adapt instructional practices to support included students.

- Teachers want to help students with disabilities experience academic success.

- Teachers will perceive the CRIME model as useful.

\section{Terms}

For the purpose of this study, it is necessary to explain terms related to this project. Accommodations, adaptation, children with disabilities, collaboration, general education, IEP, inclusion, IDEA, and special education are defined as follows:

- Accommodations: Any technique that alters academic tasks, or alters an educational environment and enables students to demonstrate knowledge without being impeded by their disability. Typically, accommodations do not change or alter the information to be learned, or the amount of information to learn (Johnson, 2000).

- Adaptation: An adaptation is a modification to the delivery of instruction, to the method of instruction, or to student performance requirements that changes the content or conceptual difficulty of the curriculum (King-Sears, 1997).

- Children with disabilities: A child that has met the qualifying criteria of the IDEA ( 2004), and is classified as having one of the disabilities specified in the act: mental retardation, hearing impairments, speech or language impairments, visual impairments, serious emotional disturbance, orthopedic impairments, autism, traumatic brain injury, other health impairments, and/or specific learning disabilities. 
- Collaboration: A style of interaction between coequal parties who voluntarily engage in shared decision making as they work toward a common goal (Friend \& Cook, 2003). Teachers who collaborate share responsibility for decisions, and are jointly responsible for outcomes.

- General Education: In general education classrooms, the focus is on teaching content. Instruction is provided to large groups, and is not specialized or individualized to meet the needs of specific individuals.

- Individualized Education Program (IEP): Every student who qualifies for special education services has an IEP. The IEP outlines the student's educational program, specifies related services, states the amount of time the students will spend in the general education classroom and in the resource classroom, and describes educational accommodations that will be provided for the student.

- Inclusion: Inclusion refers to educating students with disabilities in general education classes rather than educating them in separate environments. According to IDEA (2004), students with disabilities who are included in general education classes should be provided supplementary aids and support services so that they can benefit from the educational placement in the general education classroom.

- Individuals with Disabilities Act (2004): Federal legislation that mandated that children with disabilities are to receive free and appropriate education provided at public expense. 
- Special Education: Special education is instruction that is specially designed to meet the unique needs of students who have specific disabilities. Special education instruction may be provided in general education classrooms, in special education classes, in hospitals and other institutions, and/or in a child's home. 


\section{CHAPTER II}

\section{REVIEW OF THE LITERATURE}

As inclusive movements have significantly impacted the field of special education, collaboration between special and general education teachers has become increasingly important for providing students with disabilities individualized adaptiveinstruction, and access to general education curriculum. The first section of this review addresses the legal, social, and philosophical influences on inclusion, and is followed by a discussion of inclusion and collaboration.

\section{Factors That Have Influenced Inclusion}

During the past 50 years, the prospects for receiving access to public education have improved for students with disabilities. Prior to the enactment of the Education for All Handicapped Children Act (EAHCA, 1975), students with disabilities were often excluded from public education. In fact, prior to 1975, thousands of students with disabilities did not attend school (Rothstein, 2000). Today, students with disabilities have access to public education. And, not only are students with disabilities educated in public institutions, their numbers in general education classes have increased during the last 20 years. In 1988, 30\% of students with disabilities were included in general education classes for more than $80 \%$ of the school day; with $70 \%$ of students with disabilities not included in general education classes for the majority of the school day. Today, the number of students with disabilities included in general education classes has increased to 50\% (National Center for Education Statistics, 2002). 
As more students with disabilities have been instructed in general education classes, the field of education has had to adopt new practices to support inclusion. Inclusion, as defined in research literature is a practice that:

Embraces the vision that all students be served in their neighborhood schools in the general classroom with individuals their own age. Inclusive schools are restructured to be supportive, nurturing communities that meet the needs of all individuals within them, with substantial resources and support for students and teachers. (Mercer \& Mercer, 2005, p. 18)

Meeting the needs of all learners does not occur by simply placing children with disabilities in inclusive classrooms. As this definition of inclusion states, schools must be restructured in order to support the needs of diverse learners. Specifically, special and general educators must work together to effectively support inclusion. Beloin (1998) stated that inclusion is a bridge connecting personnel from special education and general education; and, change can be embraced when educators work together and share a common vision for educating all students. In this section, the legal, social, and philosophical influences that have supported changing education to include all learners are presented.

\section{Legal Foundation for Inclusion}

For most of the $20^{\text {th }}$ century, federal laws did not protect the educational interests of students with disabilities. During the 1950s and 60s, civil rights movements brought changes that impacted education for students with disabilities. The landmark case of Brown v. Board of Education of Topeka (1954) precipitated significant changes in education when the Supreme Court ruled that "separate educational facilities are 
inherently unequal" and therefore a violation of constitutional rights. This ruling brought about integration, which at the time was revolutionary.

Change for all segregated groups did not occur all at once. Some students, particularly students with disabilities, were still discriminated against and denied due process and equal protection where education was concerned. In 1971, the Pennsylvania Association of Retarded Children (PARC) v. Pennsylvania and Mills v. Board of Education challenged excluding children with disabilities from public education, and petitioned the court to define educational rights for children with disabilities. In these cases, the Supreme Court applied the $14^{\text {th }}$ amendment to education and ruled that the students represented were denied due process and equal protection. Specifically, in Mills v. Board of Education, the court defined special education rights by stating that schools were required to (a) give written notice of testing, (b) obtain consent from parents or legal guardians prior to testing, (c) have procedures for hearings and appeals, and (d) allow parents to review educational records.

The PARC and Mills rulings led to congress passing the Education for All Handicapped Children Act (EAHCA, 1975). The EAHCA was the first major law that specified legal protections for students with disabilities and outlined educational practices for students with disabilities. The law mandated that students with disabilities were entitled to a free and appropriate public education (FAPE) individualized to meet their needs, and prescribed procedures for evaluating and educating students with disabilities. The specifics of the law are described below.

- The EAHCA provided due process procedures and protections,

- Required non-discriminatory testing, 
- Called for education in least restrictive environments (LRE),

- Specified parental involvement and consent, and

- Provided for individualized education for students with disabilities with the Individualized Education Program (IEP).

In subsequent years, following the enactment of the EAHCA, courts affirmed the LRE provision of the EAHCA. They ruled that students with disabilities were to be included to the maximum extent possible in classes with their non-disabled peers, and were to be provided supplemental aides and supports when necessary to enable them to benefit from education in general education classes. In Roncker v. Walter (1983), students with disabilities were educated in separate facilities. The $6{ }^{\text {th }}$ Circuit Court ruled that before segregating students with disabilities, school districts should evaluate what makes a separate facility superior to the general education facility, and incorporate the superior aspects of the separate facility into general education classes. In addition to creating appropriate educational facilities for students receiving special education services, in Board of Education v. Rowley (1982) and in Daniel R.R. v. State Board of Education (1989), the courts ruled that students with disabilities should be provided necessary supplemental aides and supports that will enable them to benefit from their education in the general education setting. Not only do schools have to provide supplemental aides and supports, they have to provide a full array of implemented supports before schools are justified in moving students with disabilities out of general education classrooms (Oberti, 1993).

Following these court rulings, the U.S. Congress passed laws aimed at improving education for all students, which also impacted students with disabilities. Historically, 
students with disabilities were excluded or exempted from taking state and district assessments, which meant that they were not held to the same academic standards as students without disabilities. Beginning with Goals 2000: Educate America (1994), lawmakers enacted laws that required students with disabilities to participate in state assessments. Included in Goals 2000 was a provision to provide accommodations and adaptations as necessary to allow students with disabilities to participate in state assessments (Shriner, 2000).

The same year Goals 2000 became law (1994), legislators also passed the Improving America's Schools Act (IASA). IASA required districts and schools that receive Title I funds to implement standards-based accountability systems that included multiple assessments (Shriner, 2000). This law stated that students with disabilities must be included in the assessments, and achievement data for students with disabilities should be extracted from the data of the testing group.

The Amendments to the Individuals with Disabilities Act (IDEA) of 1997, included elements of both Goals 2000 and IASA. Specifically, the 1997 IDEA Amendments included the following requirements:

- Children with disabilities were to be included in general state and district assessment programs with appropriate accommodations where necessary.

- The IEP must list accommodations and modifications students need to participate in state and district assessments, reasons for not participating if students will not participate in assessments, and describe means of assessing student performance. 
With these requirements and the provision that educators state to what extent students with disabilities would not participate in general education classes, the amendments made explicit the assumption that children with disabilities should participate in and be assessed against the general education curriculum. Not only did the amendments clarify that students with disabilities were expected to progress in general education curriculum, the amendments also required educators to specify related services, supports, and classroom modifications necessary to enable students with disabilities to progress (IDEA, 1997; Roberts, 2001).

Finally, the most recent statue, No Child Left Behind (NCLB, 2001), requires schools to report on school-wide academic progress. School-wide annual yearly progress is measured by assessing all students in elementary and secondary schools, including students with disabilities.

Together, the body of special education law, education reform laws, and court rulings, have consistently conveyed the ideology that students with disabilities should be (a) educated with their peers to the maximum extent possible, (b) provided access to grade level curriculum, and (c) provided the necessary supports and aides that will allow them to benefit from their education.

\section{Societal and Philosophical Influence}

Laws and court rulings are not the only influences on special education practice. Gallagher (1994) argued that larger societal movements have significantly influenced special education. Throughout the $1950 \mathrm{~s}$ and $60 \mathrm{~s}$, civil rights leaders fought to procure equal rights for unprotected minority groups. As civil rights leaders influenced public policy, special education researchers responded by arguing for changes in special 
education. Kavale and Forness (2000) stated that Dunn's (1968) influential article must be placed in the context of the strong antisegregation sentiments of the 1960s. In his article, Dunn questioned whether separate special education classes were justifiable. Although Dunn's article lacked scholarly rigor, it influenced others to support the idea of abandoning special education classes (Kavale \& Forness, 2000).

As discussed in the legal section, the civil rights antisegregation agenda influenced special education law, and continued to influence policy makers beyond the 1950s and 60s. In 1986, the Regular Education Initiative (REI) written by Madeline Will, the Assistant Secretary of the United States Department of Education, called for more inclusive placements with the goal of merging general and special education to create a more unified system of education (Will, 1986). The REI was based on the following assumptions:

- Students are more alike than different.

- Special instruction is not required.

- Good teachers can teach all students.

- All students can be provided with a quality education without reference to traditional special education categories.

- General education classrooms can manage students without segregation.

- Physically separate education is inherently discriminatory and inequitable.

Although Will sought to combine special education and general education classes into a single service delivery model, in reality the REI became a special education initiative for high-incidence disabilities. It had a modest influence on special education; but, little influence on general education (Kavale \& Forness, 2000). 
The inclusive schools movement on the other hand, with the larger goal of reducing the continuum of placements offered to students with disabilities, has been more influential and continues to impact the field of special education (Kavale \& Forness, 2000). The group that significantly influenced the full inclusion movement was The Association of Persons with Severe Handicaps (TASH). TASH called for an elimination of special education in the form of a continuum of placements, and promoted a curriculum that emphasized socialization over academic achievement (Stainback \& Stainback, 1991). As TASH called for full inclusion, the anticipated effect was that the general education system would be forced to deal with students they had excluded, and would transform into a system that could meet the needs of all students (Kavale \& Forness, 2000).

Although TASH promoted full inclusion, there is not agreement that abandoning special education programs is the only way to meet the needs of students with disabilities. Gallagher (1994) argued that reforming educational systems is not the answer. He questioned the assumption that students with disabilities or with mental retardation should be studying the same curriculum as students without disabilities. He suggested that special education should design curriculum that delineates tasks and skills exceptional children need to learn to become effective workers and citizens. Gallagher pointed out that a flaw in full inclusion thinking is that fairness "consists of educating all children in the same place at the same time (and with the same curriculum)" (p. 528). Instead, he stated that fairness consists in ensuring that the basic needs of students with disabilities are met when they are prepared for careers and satisfying lifestyles. 
Today, philosophical movements continue to influence debates about inclusion and the nature of disabilities. Individuals in special education who support larger movements of post-modern multiculturalism continue to advocate social reform and full inclusion. As philosophical movements, multiculturalism and post-modernism are characterized by disbelief in universal systems of thought. The philosophies advance a reaction against a positivist, empirical approach of describing generalizable truths (Creswell, 1998). Post-modern philosophers do not believe there is a stable foundation to support universal and objective reality. They believe that instead of mirroring reality, knowledge is a social construction set within the conditions of the world and in the multiple perspectives of class, race, gender, and other group affiliations (Creswell, 1998; Kvale, 1996). Included in the conditions of the world are different discourses and the importance of marginalized people. Discourse and marginalized people must be elevated as societal constructions of power and hierarchy must be deconstructed (Creswell, 1998).

In special education, some argue that the medical model (assessment, diagnosis, and prescription) is a power construction that should be deconstructed. Fitch (2002) stated that the "medical model of disability intersects with forms of oppression in complex and pervasive ways. It plays a pivotal role in maintaining an 'ability' tracked system of education that covertly segregates by race, class, and ethnicity" (p. 477). According to Fitch, the medical model should be replaced with multicultural ideology. He stated, "Fundamentally, [multicultural philosophy] means interrogating and transforming the norm itself, changing the discursive representations and institutions that produce inequality and exclusion" (p. 474). 
Baglieri and Knopf (2004) continued the argument that difference, traditionally ascribed to students with disabilities, should be emphasized as natural and acceptable. Although inclusion promotes social justice, some inclusive practices such as singling out students with disabilities as needing individualized attention and instruction continue to marginalize students with disabilities. Instead, they suggested "that a truly inclusive school reflects a democratic philosophy where all students are valued, educators normalize difference through differentiated instruction [for all students], and the school culture reflects an ethic of caring and community" (p. 525). Ho (2004) agreed with Baglieri and Knoph (2004). She advocated examining the social construction of classrooms, and suggested that instead of treating learning difficulties like an illness, educators should examine educational environments to determine if they support diverse learning patterns.

Not all researchers agree with this perspective and share post-modern beliefs about rejecting scientific research and knowledge. As evidenced by the NCLB support of scientifically-based practice, there is also a strong movement in society and in education that supports scientific research and interventions. Dansforth (2005) described the goal of empirical inquiry as being to objectively uncover approaches and tactics that produce positive effects in the education and treatment of children with disabilities. The expectation of using scientific research is that scientists and researchers will determine best practice based on knowledge they believe is generalizable.

Those who support empirical inquiry believe that the best hope for helping students with disabilities is through science. Kauffman (2005) stated that if we accept post-modern assumptions that all realities are constructions and power relations, we will 
be left with cognitive debris of which the causalities will be students with disabilities. Hallahan (2005) argued that failure in general education is what placed students with disabilities in special education classes in the first place. He expressed his belief that disabilities are life-long conditions, and that by ignoring learning differences, educators risk neglecting students' instructional needs. Hallahan believed that students with disabilities need more intense individualized instruction, not less.

Together, legal and social/philosophical movements support and promote inclusion. But, there is disagreement as to the best way to comply with IDEA and educate students with disabilities. Three service delivery models have emerged for students with high-incidence disabilities (a) remedial services provided in special education classrooms, (b) inclusion with related services and support, and (c) inclusion with environmental adaptations (see Figure 1). 


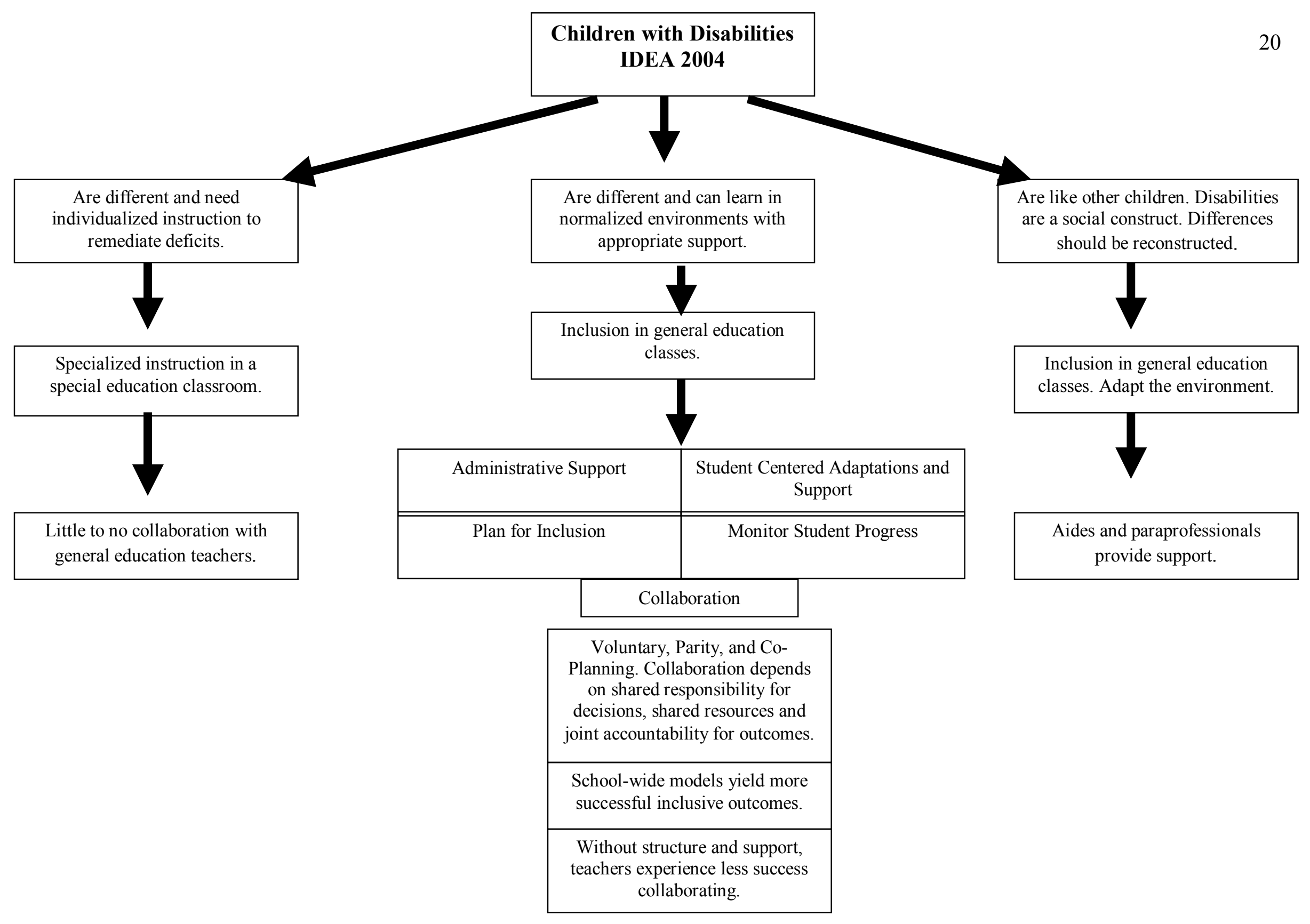

Figure 1. Concept map of the relationship between different philosophies of inclusion and collaboration. 


\section{Inclusion and Collaboration}

Inclusion

Regardless of whether or not the special education community embraces postmodern philosophies or empiricism, classroom practices should comply with laws requiring least restrictive environments (LRE), access to general education curriculum, and individualized instruction designed to meet the needs of the individual--with adaptations and accommodations as necessary. According to Lipsky and Gartner (2005), if inclusion is going to become the prominent model, the following elements will be required (a) visionary leadership, (b) collaboration, (c) focused use of assessment, (d) support for staff and students, (e) appropriate funding levels and formulas, (f) parental involvement, (g) effective program models, (h) curriculum adaptations, and (i) effective instructional practices. Additionally, Schumm and Vaughn (1995) listed factors that contribute to successful inclusion.

1. The first priority is the student's progress. Ongoing assessment, monitoring, and placement consideration is critical.

2. Teachers should self-select involvement.

3. Considerable resources related to personnel and materials are required for inclusive classrooms and should be made available.

4. School-site personnel develop models that evaluate and meet the needs of students.

5. A range of educational programs are available to meet the needs of students with learning disabilities.

6. The service model is evaluated in terms of whether or not it meets the needs 
of students with disabilities.

7. Professional development is required at the school-site level.

8. Teachers and other key personnel discuss and develop their own philosophy of inclusion. This philosophy guides practice and sets the tone for accepting students with disabilities.

9. The classroom curricula and instructional practices are designed to meet the needs of all students.

Of the elements listed, research indicates that successful inclusion depends on collaboration (Amato, 1999; Burnstein et al., 2004; Hunt et al., 2003). In order to provide access to general education curriculum, and to plan and implement instructional and curricular accommodations necessary for students with disabilities to access the general education curriculum, special education and general education teachers must work together--each contributing their expertise to create instructional environments supportive of students with disabilities. "For both educators and related service providers, the art of collaboration needs to be valued within the school climate as necessary to inclusive practices and professional growth" (Bassett et al., 1997, p. 379).

\section{Collaboration}

Collaboration in education is defined as coequal professionals voluntarily coplanning to achieve common goals (Friend \& Cook, 2003). Teachers who collaborate effectively share responsibility for decisions, share resources, and assume joint responsibility for outcomes. These elements of collaboration can be present in various collaborative relationships. Friend and Cook (2003) discussed collaborative structures as including collaboration between two professionals, collaborative pairing, and co- 
teaching. In one-to-one collaboration, collaboration is defined as a style of direct interaction between at least two coequal who share common goals and voluntarily participate. Collaborative pairing is different in that a group of individuals from different disciplines contribute their unique skills to cooperatively solve problems. Co-teaching involves two credentialed professionals jointly delivering instruction, teaching a diverse group of students, and sharing classroom space.

In addition to the structures described above, Coben, Thomas, Sattler, and Morsink (1997) described collaborative consultation as a form of collaboration. Collaborative consultation combines characteristics of collaboration (e.g., mutual goals, voluntary participation, and shared resources), with elements of consultation, which involves professionals with diverse expertise sharing information to generate solutions to mutual problems (Coben et al., 1997).

School-wide collaboration. Whether teachers work together in one-to-one interactions, participate in collaborative pairs, co-teach, or employ collaborative consultation structures, successful collaboration often depends on teachers expending effort to develop effective relationships, and school principals and administrators supporting teachers' collaborative efforts. When this happens, teachers can devote time and energy to serving the needs of students with disabilities included in general education classes (Amato, 1996; Burnstein et al., 2004). In three school districts in California, administrators provided teachers with the support necessary to change school practices to support inclusion (Burnstein et al., 2004). The change processes the districts implemented included preparing for change by sharing vision and securing commitment for inclusion, training teachers with skills needed to implement change; and finally, supporting teachers 
as they worked together to adjust classroom practices to include students with disabilities in general education classes.

As part of the Burnstein et al. (2004) study, administrators, teachers, and parents were interviewed about their perceptions of the inclusive practices. Although most of the schools in these school districts implemented a variety of service delivery models (pullout instruction and full inclusion), teachers from elementary and middle schools consistently discussed the importance of collaboration in terms of supporting students with disabilities included in general education classes. At one school, the special education and general education teachers met monthly to collaboratively plan and implement practices designed to support students with special needs. Substitute teachers were hired to float to enable the teachers to meet together. As a result, the teachers were able to focus their energies on providing classroom support for students with disabilities, and for students at-risk for school failure. And, at the end of the study, both teachers and parents believed that the students with disabilities benefited academically when instruction and classroom practices were adapted to meet the needs of the students.

School-wide systems can not only support teachers in collaborative planning, the systems can also provide structure that focuses collaborative planning. Freedom School, in Santa Cruz, California, implemented a collaborative pairing model designed to address problems of fragmented relationships between general education and special education teachers (Amato, 1996). The model, facilitated by the principal, included a pair of general education teachers, family advocates, and special education staff. All teachers in the school reviewed their classroom practices with the pair, and identified students in their classes at-risk for failure. The pair then utilized school resources to plan and implement 
supports to address the needs of the students at-risk for school failure. Over the course of five years, the number of students referred for education dropped dramatically, as did the number of students who qualified to receive special education services.

Structured collaboration. Students with and without disabilities are impacted by effective collaborative practices. Hunt et al. (2003) conducted a study at two elementary schools that unlike Freedom Elementary, did not implement a school-wide model. In this study, Hunt et al. (2003) organized collaborative pairs to investigate the effectiveness of Unified Plans of Support as a model for developing classroom supports for students with severe disabilities and at-risk for school failure. The main elements of the Unified Plan of Support were (a) regularly scheduled pair meetings, (b) the development of classroom supports for students, (c) built-in accountability, and (d) flexibility to change ineffectual supports. The collaboration pairs at both schools planned and implemented classroom supports designed to increase the targeted students' academic and social involvement in the general education classroom. As the United Plans of Support were implemented, and student progress tracked, research data showed that the students' academic and social engagement in classroom activities increased.

These research studies described schools that used structured collaborative frameworks and supported teachers in collaborative processes. Collaborative practices in these schools were consistent with definitions of collaboration. Unfortunately, not all schools implement practices that support teacher collaboration, or provide structure for collaborative processes. As a result, teachers have reported problems associated with collaborating. 
Challenges reported. One problem reported is teachers fail to collaboratively plan supports for students with disabilities--they often share information rather than jointly solving problems. Foley and Mundschenk (1997a) surveyed 407 secondary special education teachers about their perceptions of collaboration. The teachers' responses indicated that the special educators interacted frequently with general education teachers. However, the teachers reported that the majority of their interactions focused on sharing information rather than on collaborative problem solving or planning. In another study, Foley and Mundschenk (1997b) surveyed general education teachers about their collaborative interactions with special education teachers. Forty-six percent of the teachers reported infrequent interaction with special educators. Foley and Mundschenk concluded that the infrequent interactions suggested that the secondary school teachers were either not serving students with disabilities or they were unaware that students with disabilities were enrolled in their classes.

Even when general education teachers are aware of students with disabilities who are included in their classes, they may not address the academic needs of the students if they do not collaborate with special education teachers to plan appropriate educational supports. In a case study, Brice and Miller (2000) described the experience of a student with mild disabilities who was included in a general education elementary class. The student was fully included in the general education classroom, but was not provided supports necessary to enable him to access the general education curriculum. In this research report, the general education teacher did not collaborate with the special education teacher to plan appropriate instruction for the student. Instead, the teacher assigned a paraprofessional to work with him. The paraprofessional moved the student to 
the back of the classroom, and kept him segregated from the rest of the class. In this study, the student was denied access to the general education curriculum.

When special education and general education teachers fail to plan how students with disabilities will access classroom curriculum, students with disabilities can be excluded from general education curriculum. Fox and Ysseldyke (1997) observed inclusive classes in a suburban middle school. Prior to including students with disabilities in general education classes, the special education department developed an inclusion plan designed to address issues related to including students with disabilities in general education classes. The plan depended upon staff training, ongoing planning and problem solving meetings, collaboration, and support from the school principal. Because the plan was developed by the special education staff without input from general education teachers, the teachers did not jointly share responsibility for academic outcomes, and the teachers did not develop effective working relationships. When students with disabilities experienced difficulty in particular classes, they were removed from the general education classes.

Without appropriate support and individualized instruction, students with disabilities have difficulty accessing general education curriculum. Over the course of two years, Stockall and Garten (2002) observed inclusive practices in an elementary school. Using information obtained from direct observations, Stockall and Garten reported that the general education teachers rarely adapted instruction to meet the needs of individual students. Although the general education teachers reported obtaining ideas from special education teachers, they did not report collaborative planning sessions. Most of the classroom accommodations in this school consisted of changing a teaching 
approach for the whole class rather than adapting instruction to meet the needs of a single student. Often, peer-mediated strategies were used extensively, and reading instruction became the responsibility of untrained peer tutors.

As the Stockall and Garten (2002) study illustrated, talking and obtaining ideas from special education teachers is not the same as collaborative planning where teachers are committed to meeting common goals for educating their students. Collaborative planning is necessary for planning classroom supports for students with disabilities. If teachers fail to collaborate to plan supports for students with disabilities, it is not surprising that general education teachers report that they do not individualize instruction and provide instructional adaptations and accommodating to meet the needs of students with disabilities included in their classes.

Although information is available on how to make classroom accommodations and adaptations, research reports indicate that general education teachers do not always provide accommodations for students with disabilities. Passe and Beattie (1994) conducted a research study designed to acquire information about the extent that general education social studies teachers in elementary, middle, and high schools adapted instruction and made accommodations for students with disabilities. They surveyed teachers in five school districts and reported that the teachers lacked time, materials and knowledge to adequately provide meaningful accommodations for students with disabilities in their classrooms. Specifically, the teachers reported that they provided peer tutoring; however, the tutoring typically consisted of asking a peer to help students with disabilities when the students had questions or experienced difficulty completing assignments. They did not report training the peers. The teachers reported that they 
altered seating arrangements for students with disabilities. When they altered seating arrangements, they reported that they placed students with disabilities next to peers who could answer their questions. In regards to altering or adapting instruction or materials, the teachers reported that they attempted to find appropriate materials for the students with disabilities; but, when they couldn't find simplified versions of classroom texts, they provided books that at times addressed different topics than what the class was studying. Finally, homework accommodations were limited. The teachers reported that they either reduced assignments for students with disabilities, or excused them altogether.

Adaptive instruction and accommodations. It is difficult for students to acquire skills when teachers do not provide individualized adaptive instruction. Baker and Zigmond (1995) observed inclusive classes in five schools, and Stockall and Garten (2002) observed inclusive practices in one elementary school. Both research studies reported that the teachers did not provide adaptive education, which they defined as direct or focused interventions designed to improve each student's capabilities. Instead, the teachers often utilized untrained peer-tutors and paraprofessionals to remediate skill deficits in students with disabilities. Even during small group instruction, the teachers did not focus on skills or strategies the students needed for lessons, which then impacted academic achievement for the students with disabilities.

Similar to the above studies, Fletcher, Bos, and Johnson (1999) observed instruction for learning disabled English-Language Learners (ELL) with learning disabilities. Although the instruction was provided in a bilingual classroom, Fletcher et al. (1999) observed that the instruction was similar to general education instruction in that the teachers did not make accommodations and adaptations to meet the needs of the 
students with disabilities. Instead, they provided whole-group instruction, and gave the students with disabilities the same learning materials and assignments as the other students in the classroom. As a result, the students with disabilities participated less frequently, required more assistance to complete assignments, and frequently appeared frustrated.

Time, available materials, and training influence whether teachers make accommodations. Teacher attitudes toward accommodations also impact the accommodations teachers use in the classroom. Bryant, Dean, Elrod, and Blackbourn (1999) surveyed rural general education teachers about their opinions of accommodations. Some of the accommodations the elementary school teachers rated most acceptable were open book exams, dictation on tests, reading items to students, and giving tests in special education classes. They preferred accommodations that they perceived were most realistic to implement such as making phone calls to parents, and rated accommodations that did not alter the type or amount of information as realistic, fair, and effective.

In another study, whether teachers perceived accommodations to be acceptable and useful impacted their opinions of various accommodations. Polloway and Bursuck (1996) surveyed teachers about their willingness to make homework, testing, and grading adaptations. Teachers in this study expressed a willingness to make accommodations for students with disabilities. Factors that impacted their willingness to make accommodations were whether they believed suggested accommodations were acceptable or useful. For example, teachers rated checking for understanding as a useful accommodation. Keeping students after school to complete assignments they rated as not 
useful. Polloway and Bursuck reported that perceptions about the acceptability and usefulness varied from teacher to teacher, and specific accommodations needed to be considered on a student by student basis.

Munk and Bursuck (1998) also surveyed teachers about their perceptions of report card adaptations for students with disabilities. Of the 368 elementary and secondary teachers they surveyed, the teachers reported that although they perceived that making grade adaptations such as basing grades on improvement as helpful, $73 \%$ had concerns that grading adaptations used only for students with disabilities were unfair. Fairness to other students was an issue for some of the general education teachers.

In addition to having concerns about equality and utility, training related to instructional strategies influences teachers' ability to implement appropriate accommodations. deBettencourt (1999) surveyed 71 general education teachers. In this survey, deBettencourt reported that general education teachers who had not taken classes on educating children with disabilities had lower scores for using instructional strategies. Although the teachers reported that they used instructional strategies, they did not use research-based strategies such as advance organizers, learning strategies, and metacognitive strategies.

It is important for teachers to implement effective instructional strategies because students with disabilities can improve their academic performance when they have appropriate academic support. Providing text accommodations is one way teachers can support students with disabilities who have difficulty reading. Boyle et al. (2003) reported on the effects of a specific text accommodation related to content. Secondary students with learning, speech, behavioral, and other disabilities were provided with CD- 
ROM audio textbooks for their history classes. After using the audio textbooks to access content material, students in two experimental groups achieved higher quiz and cumulative test scores. Boyle et al. (2003) concluded that using audio textbooks has promise as a specific accommodation for students with mild cognitive disabilities. Teachers in this study reported that the audio textbooks provided students with disabilities access to a generalized classroom routine for expository reading.

Students with disabilities benefit when teachers adapt instruction to meet their academic needs. But, barriers to collaborative processes must be addressed before teachers can plan and implement supports for students with disabilities. As discussed previously, without structure, teachers often fail to collaboratively plan. General education teachers have also reported that they lack information on how to adapt classroom practices to meet the needs of students with disabilities (Edmunds, 2000; Heflin \& Bullock, 1999; Kamens et al., 2003; Scruggs \& Mastropieri, 1996).

CRIME model. To address problems associated with collaboration, and to help general and special education teachers focus collaborative efforts on planning classroom supports for students with disabilities included in general education classes, Prater (2003) designed a collaboration model (Curriculum, Rules, Instruction, Materials, Environment, [CRIME]) that guides the collaborative planning process for special and general education teachers. This model can be implemented by teachers in any school. It provides structure for collaborative planning, and leverages the strengths of both special and general education teachers.

The CRIME model process involves comparing the general education classroom environment with a student's learning profile in order to plan individualized learning 
supports. Ideally, this process should help general education teachers understand the educational needs of students with disabilities included in their classroom, and allow special education teachers to contribute their expertise on adaptations and accommodation so that they both plan an educational environment that is supportive and conducive for learning.

The four steps of the CRIME model process are (a) evaluate the curriculum, rules, instruction, materials, and environment of the general education classroom, (b) list the student's learning and behavioral strengths and limitations, (c) compare the classroom environment with the student's profile to identify learning facilitators and barriers, and (d) plan adaptations and accommodations that will facilitate learning and mitigate the effect of learning barriers.

There are a number of ways that teachers can implement instructional adaptations and accommodations. Specifically, teachers can adapt content, process, and products (Prater, in press). Content refers to adapting what the teacher teaches, and how the student accesses the material (Tomlinson, 2001). Process accommodations involve changing how the teacher instructs and how the student is expected to respond to the instruction (Prater, in press). When teachers make adaptations and accommodations for products, they address a student's needs in terms of how a student completes independent assignments, and what assignments the student is expected to complete (Prater, in press). Table 1 provides examples of how teachers can accommodate and adapt content, process, and product (Deschenes, Ebeling, \& Sprague 1994). 
Table 1

Examples of Classroom Accommodations and Adaptations

Accommodations Descriptions
and adaptations

Content

- Size: The amount of content to be learned.

- Difficulty: The difficulty level associated with the content.

- Alternate Goals: Adapt the goals or outcomes related to the content material.

- Substitute Curriculum: Use different materials to meet the student's goals.

Process

- Input: The way instruction is delivered.

- Level of Support: The amount of assistance provided for the student.

- Time: The amount of time to allotted for learning.

- Participation: The extent the learner is expected to participate.

Product

- Time: The amount of time allotted to complete assignments.

- Output: The manner in which the student completes assignments and demonstrates learning. 
The CRIME model has not been evaluated in research studies, and researchers have not investigated teachers' perceptions of models, like the CRIME model, that can be used by pairs of special and general education teachers who teach in schools that do not implement school-wide collaboration models. Given that many schools do not implement school-wide collaboration models, and teachers experience challenges associated with collaborative planning processes, research suggests that teachers could benefit from using structured collaboration models.

In summary, federal law requires schools to (a) educate students with disabilities in LRE, (b) allow students with disabilities to access general education curriculum, and (c) provide students with disabilities the necessary supports and supplemental aids that will enable them to benefit from their education. For this to happen, collaboration is essential. But, teachers experience difficulty collaborating to plan educational supports for students with disabilities. More research needs to be conducted about collaborative processes to acquire information as to what contributes to effective collaboration. Specifically, because many special and general education teachers do not have schoolwide support for collaboration, and teachers struggle to both plan and implement accommodations for students with disabilities, research studies should investigate whether specific collaboration models can facilitate collaboration between special and general education teachers and guide the process of planning classroom supports for students with disabilities. 


\section{CHAPTER III}

\section{METHOD}

This study was a qualitative phenomenological study that investigated the nature of a collaboration experience when special and general education teachers used the CRIME model (Prater, 2003) to plan instructional accommodations and adaptations for students with disabilities included in general education classes. The design of the research study is discussed in the following sections.

\section{Research Relationship}

For this study, the researcher interacted with the participants twice, once to train them to use the CRIME model, and a second time to interview the participants about their experience. Because this study investigated the collaborative relationship between special and general education teachers as they used a structured framework for collaborative planning, the researcher interacted with the participants as little as possible during the training process. The researcher described and taught the CRIME model and did not specifically discuss concerns related to students at the teachers' schools.

The researcher was not present when the teachers completed the CRIME process. The researcher interviewed the teachers within one week of when they completed the process. Each research interview took between 30 to 45 minutes to complete.

\section{Participants}

Twelve elementary school teachers participated in this study--six special education teachers and six general education teachers. Teachers were selected to participate if they (a) were licensed in their respective fields, (b) were teaching in an elementary school that practiced either pull-out resource instruction, or full inclusion, (c) 
agreed to sign a consent form indicating that they would commit to participating in the CRIME model training, completing the CRIME process, and being interviewed about their experience, and (d) had at least one student with disabilities included in a general education class for at least $70 \%$ of the school day.

The researcher recruited participants by networking with teachers and university faculty to obtain recommendations of special education teachers who might be willing to participate in the research study. From the recommendations, the researcher contacted the teachers, explained the project, and determined if a referred teacher was, or was not willing to participate in the project. When a special education teacher met the selection criteria and agreed to participate in the project, the researcher asked the teacher to arrange for a general education teacher at his/her school to partner with him/her for the collaboration project. Table 2 provides demographic information about the teachers who consented to participate in this study.

Table 2

\section{Teacher Demographics}

\begin{tabular}{lllll}
\hline Teacher & $\begin{array}{l}\text { Grades } \\
\text { teaches }\end{array}$ & $\begin{array}{l}\text { Years } \\
\text { taught }\end{array}$ & Major areas of study & Level of education \\
\hline $\begin{array}{l}\text { Special education } \\
\text { teacher 1 }\end{array}$ & $\begin{array}{l}\text { Grades } \\
1-3\end{array}$ & 10 & $\begin{array}{l}\text { Special Education, } \\
\text { English as a } \\
\text { Second Language } \\
\text { (ESL) and } \\
\text { Reading Endorsement }\end{array}$ & $\begin{array}{l}\text { Bachelor's degree } \\
\text { plus graduate credits }\end{array}$ \\
\hline $\begin{array}{l}\text { Special education } \\
\text { teacher 2 }\end{array}$ & $\begin{array}{l}\text { Grades } \\
4-6\end{array}$ & 2 & $\begin{array}{l}\text { Elementary Education } \\
\text { and Special Education }\end{array}$ & $\begin{array}{l}\text { Bachelor's degree } \\
\text { plus graduate credits }\end{array}$ \\
\hline $\begin{array}{l}\text { Special education } \\
\text { teacher 3 }\end{array}$ & $\begin{array}{l}\text { Grades } \\
4-6\end{array}$ & 16 & $\begin{array}{l}\text { Special Education and } \\
\text { English }\end{array}$ & $\begin{array}{l}\text { Bachelor's degree } \\
\text { plus graduate credits }\end{array}$ \\
\hline $\begin{array}{l}\text { Special education } \\
\text { teacher 4 }\end{array}$ & $\begin{array}{l}\text { Grades } \\
4-6\end{array}$ & 2 & $\begin{array}{l}\text { Special Education and } \\
\text { Fine Arts }\end{array}$ & $\begin{array}{l}\text { Bachelor's degree } \\
\text { plus graduate credits }\end{array}$ \\
\hline
\end{tabular}




\begin{tabular}{lllll}
\hline $\begin{array}{l}\text { Special education } \\
\text { teacher 5 }\end{array}$ & $\begin{array}{l}\text { Grades } \\
4-6\end{array}$ & 30 & $\begin{array}{l}\text { Physical Therapy, } \\
\text { Rehabilitative and } \\
\text { Adaptive P.E., and } \\
\text { Educational Psychology }\end{array}$ & Doctoral degree \\
\hline $\begin{array}{l}\text { Special education } \\
\text { teacher 6 }\end{array}$ & $\begin{array}{l}\text { Grades } \\
1-6\end{array}$ & 10 & $\begin{array}{l}\text { Special Education, } \\
\text { Reading }\end{array}$ & $\begin{array}{l}\text { Bachelor's degree } \\
\text { plus graduate credits }\end{array}$ \\
\hline $\begin{array}{l}\text { General education } \\
\text { teacher 1 }\end{array}$ & Grade 6 & 23 & Elementary Education & $\begin{array}{l}\text { Master's degree } \\
\text { plus extra graduate } \\
\text { credits }\end{array}$ \\
\hline $\begin{array}{l}\text { General education } \\
\text { teacher 2 }\end{array}$ & Grade 1 & 6 & Elementary Education & Bachelor's degree \\
\hline $\begin{array}{l}\text { General education } \\
\text { teacher 3 }\end{array}$ & Grade 6 & 4 & $\begin{array}{l}\text { Elementary Education } \\
\text { and ESL }\end{array}$ & Bachelor's degree \\
\hline $\begin{array}{l}\text { General education } \\
\text { teacher 4 }\end{array}$ & Grade 4 & 8 & $\begin{array}{l}\text { Elementary Education, } \\
\text { ESL, and Gifted } \\
\text { and Talented Education }\end{array}$ & $\begin{array}{l}\text { Bachelor's degree } \\
\text { plus graduate credits }\end{array}$ \\
\hline $\begin{array}{l}\text { General education } \\
\text { teacher 5 }\end{array}$ & Grade 6 & 3 & Elementary Education & Bachelor's degree \\
\hline $\begin{array}{l}\text { General education } \\
\text { teacher 6 }\end{array}$ & Grade 3 & 4 & Elementary Education & Bachelor's degree \\
\hline
\end{tabular}

\section{Setting}

Research for this project was conducted in elementary schools in a large school district in the state of Utah. The approximate number of students enrolled in the school district was 52,825 , with 5,655 of those students qualifying for special education services (Utah State Office of Education, 2003).

Elementary schools in this district implement inclusion programs in varying degrees. Inclusion programs vary from pull-out resource, where students with disabilities leave the general education class to receive specialized instruction in the special education classroom, to full inclusion programs, where the special education teacher provides services and supports in students' general education classrooms. This study was not restricted to a particular model of inclusion. However, all of the participants worked in schools that primarily implemented pull-out resource programs. 
The training meetings and interviews were conducted at the teachers' school sites in either the special education or general education teachers' classrooms. When the researcher met with the teachers to train them to use the CRIME model, the teachers determined the location for the training meeting. The researcher trained three pairs of teachers in general education classrooms, and the other three pairs in special education classrooms. All of the teachers were interviewed in their own classrooms. During the interviews and training, the teachers and the researcher sat at a table in the teachers' classrooms. The researcher met with the teachers both before and after school hours.

\section{Materials}

The researcher recorded the interviews on a portable tape recorder and used cassette tapes to tape the interviews. Transcriptions were typed on a computer and each interview was saved as a Microsoft Word document. Documents necessary for the study such as the consent to participate form, the demographic survey, and the CRIME model forms, were printed on a computer printer.

\section{Confidentiality}

All participants signed a Consent to Participate Form prior to engaging in any activity associated with the research project (see Appendix B). This form explained that participation was voluntary, that the participants' identities would remain confidential, and that all data associated with the project would be secured in a locked filing cabinet. During the course of the project, all data from this project were stored in a locked filing cabinet in the researcher's home office, and at the conclusion of the study, the cassette tapes were destroyed. In written reports about this project, the researcher did not use the names of the participants or specifically mention their schools or their school district. 
The researcher also asked the teachers to fill out a demographic survey. The completed surveys provided demographic information about the teachers, which as described above, was treated in a manner that would keep the identities of the teachers confidential. The demographic survey is included in Appendix C.

\section{Procedures}

In order to investigate the meaning of collaboration between special education and general education teachers, and to describe teachers' perceptions of the CRIME model, the design of this project was a qualitative phenomenological study. A phenomenological study explores the perceptions of participants to see how they experience and live a phenomenon. As the researcher interacts with the participants and gathers data, the researcher then seeks to understand the meaning and structure of the experience. The meaning and structure of a specific phenomenon emerges from the participants' experience, and is not imposed on the data by the researcher's own biases and assumptions (Creswell, 1998).

Although assumptions and personal bias should be set aside, the researcher does not begin the study uninformed. Anastas (2004) explained that evaluation research should be informed by prior work, and that the researcher should know the theory that informs the problem, interventions that have been used, and which have and have not worked in the past. Maxwell (2005) suggested that prior to conducting qualitative research, the researcher should create a visual representation of theory. Figure 1, included in the literature review chapter, illustrated theory related to inclusion and adaptive instruction. Existing theory informs the study, but does not control or limit the study--particularly 
during data collection when the researcher remains open to discovering new ideas and information (Anastas, 2004).

Data for this study were the completed CRIME forms and the research interviews. Before the teachers could describe their experience using the CRIME model as a framework for collaboration, they needed to learn the process of the CRIME model. The researcher treated the special education and general education teachers at each school as a pair and scheduled appointments with the pairs of teachers to teach them the CRIME process.

During the training appointments, the researcher gave each pair of teachers a set of completed CRIME forms that served as an example of how to complete the process (See Appendix D). Because the teachers who participated were experienced professionals, the researcher assumed that the basic procedures of the CRIME process (i.e., using assessment information to write a brief present level of performance statement, and analyzing instruction, curriculum, materials, the classroom rules, and environment) were within the teachers' repertoire of skills, and the researcher did not train the teachers on these procedures.

The researcher gave each set of teachers an overview of the CRIME process by telling the teachers that it is a process of comparing general education classroom practices with a student's learning strengths and limitations in order to plan supportive adaptations and accommodations. After providing an overview of the process, the researcher explained and read each step of the process using the completed example. The four steps of the CRIME model process are (a) evaluate the curriculum, rules, instruction, materials, and environment of the general education classroom, (b) list the student's 
learning and behavioral strengths and limitations, (c) compare the classroom environment with the student's profile to identify learning facilitators and barriers, and (d) plan adaptations and accommodations that will facilitate learning and mitigate the effect of learning barriers.

After the researcher explained the steps of the process and read the examples provided, the researcher then asked the teachers if they had any questions about the steps of the process, or about how to fill out the forms. For this study, other than asking the teachers if they had questions about the process or forms, the researcher did not assess whether the teachers were proficient with the process. The reason for this is a purpose of this study was to determine the teachers' perceptions of the CRIME model. If the researcher were to extensively teach and train the teachers how to use the model through role play, guided practice, etc., the training could potentially bias the teachers in favor of the model prior to completing the process themselves. In that case, the results could reflect their perceptions of the interactions of the training, and not their perceptions of the model itself.

At the completion of training, the researcher asked the teachers to fill out a checklist on whether the training procedures occurred as described above. Specifically, the teachers marked whether the researcher provided an overview of the process, read the steps of the process, read and discussed the completed examples for each step, questioned the teachers for understanding, and provided opportunity for the teachers to ask questions and make comments about the process.

Then, the researcher gave the teachers blank CRIME forms and asked them to schedule a time to complete the process together. The teachers were asked to fill out at 
least one of the sets of blank forms, and to make a copy of the completed forms to give to the researcher.

After the initial meeting with the teachers, the researcher kept in contact with the special education teacher from each pair to check on when the pair had completed the process. When the special education teacher confirmed that his/her pair had completed the process, the researcher scheduled interviews with each teacher from the pair. All interviews were conducted within one week of when the teachers met together.

The research interview was a semi-structured interview. Listed below are the questions the researcher asked during the interviews.

1. In as much detail as possible, describe your experience completing the CRIME process with the special or general education teacher.

2. What was beneficial about this process? Specifically describe elements of the process you found beneficial.

3. What was not beneficial? Specifically describe elements of the process that weren't beneficial.

4. What is your opinion of the CRIME model?

In addition to asking these questions, the researcher asked follow-up and probing questions as necessary to obtain more detailed descriptions and more specific information. For example, if a teacher stated that the pair discussed the rules in the general education class, the researcher asked the teacher to describe the specific rules and to discuss his or her perceptions of the rules. 


\section{Data Analysis}

\section{Transcribing the Interviews}

Each interview was tape recorded and then transcribed. The researcher transcribed the research interviews. Modifications to the interviews were made as the transcriptions were created. First, punctuation was added to the participants' responses. Question marks, periods, commas, and exclamation marks where added to transcripts. If a participant began a sentence, but did not complete the sentence or thought, the fragment was marked with ellipses points at the end of the last word of the fragment. Second, repeated phrases and filler words were eliminated. For example, if a participant stated "you know," or repeated the same phrase twice, the researcher deleted the phrases from the written transcription. Third, any statement that identified a participant, school, or a particular situation was changed to maintain confidentiality. If the teachers referred to each other by name, the names were deleted and a capital letter with a blank was inserted in place of the name (e.g., C___ _ Fourth, extended pauses, laughter, or any other significant expression other than normal speech were indicated by writing pause, laughed, whispered, and so forth in parentheses where the expression occurred. All typed transcriptions were saved as Microsoft Word Documents on the researcher's computer. Appendix E is a sample of a transcription.

Modifications to the interviews were made in the written research report. Quotations that were not grammatically correct according to standard written English were standardized in the written report. For example, the statement "Environment, she did this, the desks are, yes we agreed, they're close to each other;" was changed to "She discussed the environment, and we agreed that the desks are close to each other." Any 
changes in the teachers' expressions did not change the meaning of the teachers' statements.

Analyzing the Interviews

After the interviews were transcribed, the researcher analyzed the data using a typological analysis. Hatch (2002) described the steps of typological analysis as follows:

1. Identify typologies to be analyzed.

2. Read the data, marking entries related to your typologies.

3. Read entries by typology, recording the main ideas in entries on a summary sheet.

4. Look for patterns, relationship, themes within typologies.

5. Read data, coding entries according to patterns identified and keeping a record of what entries go with which elements of your patterns.

6. Decide if your patterns are supported by the data, and search the data for nonexamples of your patterns.

7. Look for relationships among the patterns identified and write your patterns as one-sentence generalizations.

8. Select data excerpts that support your generalizations. (p. 153)

For this data set, the researcher read all of the research interviews and determined that the quotations could be categorized according to themes associated with the research questions. For example, a purpose of this study was to investigate how collaboration was defined in this experience. So, quotations that described how the teachers completed the process were categorized as process quotations. Similarly, quotations that reflected elements of the CRIME process were categorized as CRIME, and quotations that 
reflected the teachers' evaluation of the experience, their student, the other teacher, the process, or the CRIME model, were categorized as evaluation quotations (See Appendix F).

After all of interview quotations were categorized into one of the main three categories, the researcher then summarized the coded statements and created tables of summarized/categorized statements for each category. When all of the quotations were summarized and added to the condensed summary tables, the researcher then looked for patterns and associations within each category and created subcategories for each of the three main categories. For example, CRIME quotations were subdivided into a classroom practices category that included curriculum, rules, instruction, materials, environment; and into a student category that included general statements, strengths, and limitations (See Appendix G).

Having identified categories and subcategories for the quotations, all of the interviews were coded using the identified patterns so that the researcher would have a record of which quotations reflected specific elements of the patterns. Prior to coding the interview, the researcher wrote code definitions for all of the codes. For example, quotations coded as CRIME quotations described elements of the CRIME process which included curriculum, rules, instruction, environment, the student's strengths and limitations, and adaptations and accommodations. Within the CRIME category, quotations coded as curriculum described the content of what the teacher teaches such as state curriculum, investigations, balanced literacy, grade level, what instruction includes (skip counting, factoring, comprehension, writing, science, character units, etc.). Appendix H provides the code definitions that were used to code the research interviews. 
Using the code definition to guide the coding process, the researcher returned to the research interviews and recoded the interviews by category and subcategory. For example, "She's not able to verbalize very quickly and fluently" was categorized as CRIME/student/limitation (See Appendix I for a sample of a coded interview). When all of the interviews were coded, the researcher reread the interviews to determine if identified patterns were supported by the data. As patterns and themes were analyzed, the researcher identified relationships among the patterns and summarized the relationships in a table that generalized the teachers' experiences (See Appendix J), and the researcher wrote paragraphs that summarized facets of the collaboration experience (See Appendix K). Throughout the data analysis process, the researcher searched for non-examples, contradictions and inconsistencies in the data.

\section{Validity}

Maxwell (2005) addressed the issue of validity threats and suggested that qualitative research proposals include descriptions of how the validity of research conclusions can be assessed. To address research validity, this researcher (a) verified the CRIME training occurred as described, (b) compared the teachers' responses to the completed CRIME forms and to the responses of the other teacher, (c) kept records of the data analysis process and had the interview coding reviewed by an independent reviewer, (d) sought for disconfirming evidence, (e) allowed the participants to review a summary of the research findings, and (f) compared the research findings with other research.

The researcher taught the CRIME model as described in the procedures section. To verify that the researcher taught the model as described, following training each participant completed a training checklist form (see Appendix L). During data collection, 
the researcher obtained a copy of the teachers' completed CRIME forms, and interviewed each teacher separately about his/her experience. The completed CRIME forms were compared to the teachers' descriptions of their collaborative experience to assess whether the teachers' descriptions of their discussions were consistent with their completed CRIME forms. For example, the special education teacher from the first pair of teachers indicated that she discussed peer tutoring with the general education teacher. However, peer tutoring was not listed as a potential adaptation on the adaptation step of the completed CRIME forms, which indicated that the topic was either not discussed as described, or not recorded on the completed forms. Also, each general education teacher's description of the collaboration experience was compared with the special education teacher's description to check for consistency between the two reports. In the above example, the general education teacher did not mention the discussion about peer tutoring, which combined with the fact that the topic was not recorded on the completed forms could indicate that the special education teacher's description of that adaptation did not occur as she described. Throughout the data analysis phase of the project, this process was used to search for contradictions and instances of inconsistent or contradictory responses in order to examine the participants' trustworthiness and to assess the validity of the data.

During data analysis, the researcher kept files of all aspects of the data analysis process. In addition to recording each step of the data analysis process, the researcher also asked an independent reviewer to review the coding of four of the coded interviews. The independent reviewer was an individual who has a bachelor's degree in elementary education. The reviewer was not associated with any other aspect of the research study. 
The researcher gave the code reviewer the code definitions and copies of the four coded interviews and asked the reviewer to indicate whether she agreed or disagreed with the codes attached to each quote. If the code reviewer agreed with the way a quotation was coded, the reviewer marked a " + " next to the code; if the reviewer disagreed with the designated code, the reviewer marked a "-" . After the reviewer rated the coding, a coding agreement percentage was calculated by dividing the total number of codes rated by the number of codes that received a "+". The agreement percentage for the interviews was $99.4 \%$.

Once the researcher had identified dominant themes in the data, the researcher again reviewed the interview data to search for disconfirming evidence. For example, a theme that emerged from the data was that when special education and general education teachers had compatible philosophies about students with disabilities, they did not experience difficulty planning accommodations and adaptations for the students with disabilities who were included in the general education teachers' classes. However, when the teachers did not have compatible philosophies about students with disabilities, they had problems with the process and did not complete the process. Once the researcher determined that compatible philosophies impacted the collaboration experience, the researcher read the interviews to find evidence that this generalization was or was not evident in all of the interviews.

Finally, the researcher wrote a summary of the research results and used electronic mail to mail a summary of the results to all of the participants. Other than thanking the researcher for providing a summary of the results, none of the participants 
commented on the final results. In the conclusion section of this report, the researcher compared the results of this study to results reported in other research studies. 


\section{CHAPTER IV}

\section{RESULTS}

This research study was a phenomenological study. A purpose of the study was to describe special education and general education teachers' experience using the CRIME model (Prater, 2003) to collaboratively plan instructional accommodations and adaptations for students with disabilities included in general education classrooms. From the teachers' descriptions of their experiences, this study defined collaboration in terms of how the teachers interacted to plan accommodations and adaptations, and also described the teachers' perceptions of the CRIME model.

\section{Structure of the CRIME Collaboration Experience}

The special education and general education teachers in this study were taught how to use the CRIME model to collaboratively plan accommodations and adaptations for students with disabilities. Six pairs of elementary school teachers used this process, and during research interviews described their experiences completing the process. From their descriptions, the structure of the experience was identified.

The CRIME process is an analytical process. The teachers analyzed their classrooms and compared their classroom practices and environments to their students' profiles. As the teachers completed each step of the CRIME process, they shared, discussed, and analyzed information about themselves, the other teacher, and the student. The process of analysis was complex. The teachers shared, discussed, and analyzed information that they filtered through their own perspectives and philosophies. Depending on the information discussed and their analysis of the information, the teachers either agreed with each other and moved through the process, or encountered 
differences that required discussion. For four pairs of teachers, the teachers discussed their differences and achieved a common understanding related to their differences, and jointly defined a problem to address. After the teachers had defined a problem to address, they jointly assumed responsibility for addressing the problem. For two pairs of teachers, they either avoided discussing their differences, or discussed their differences and did not resolve them, which impacted their collaboration experience in that they did not jointly define a problem to address, and did not complete the final step of the CRIME process together. Figure 2 illustrates the structure of the collaboration process. Each facet of the teachers' experience is described in the sections that follow. They (a) discussed CRIME elements, (b) reached consensus and/or discussed differences, (c) analyzed information according to their personal philosophies, (d) defined a problem to address, and (e) planned adaptations and accommodations. 
CRIME Process - Analyzing the general education Curriculum, Rules, Instruction, Materials, and Environment with the Student's Academic and Behavioral Strengths and Limitations

INFORMATION: Processed information related to the CRIME Process

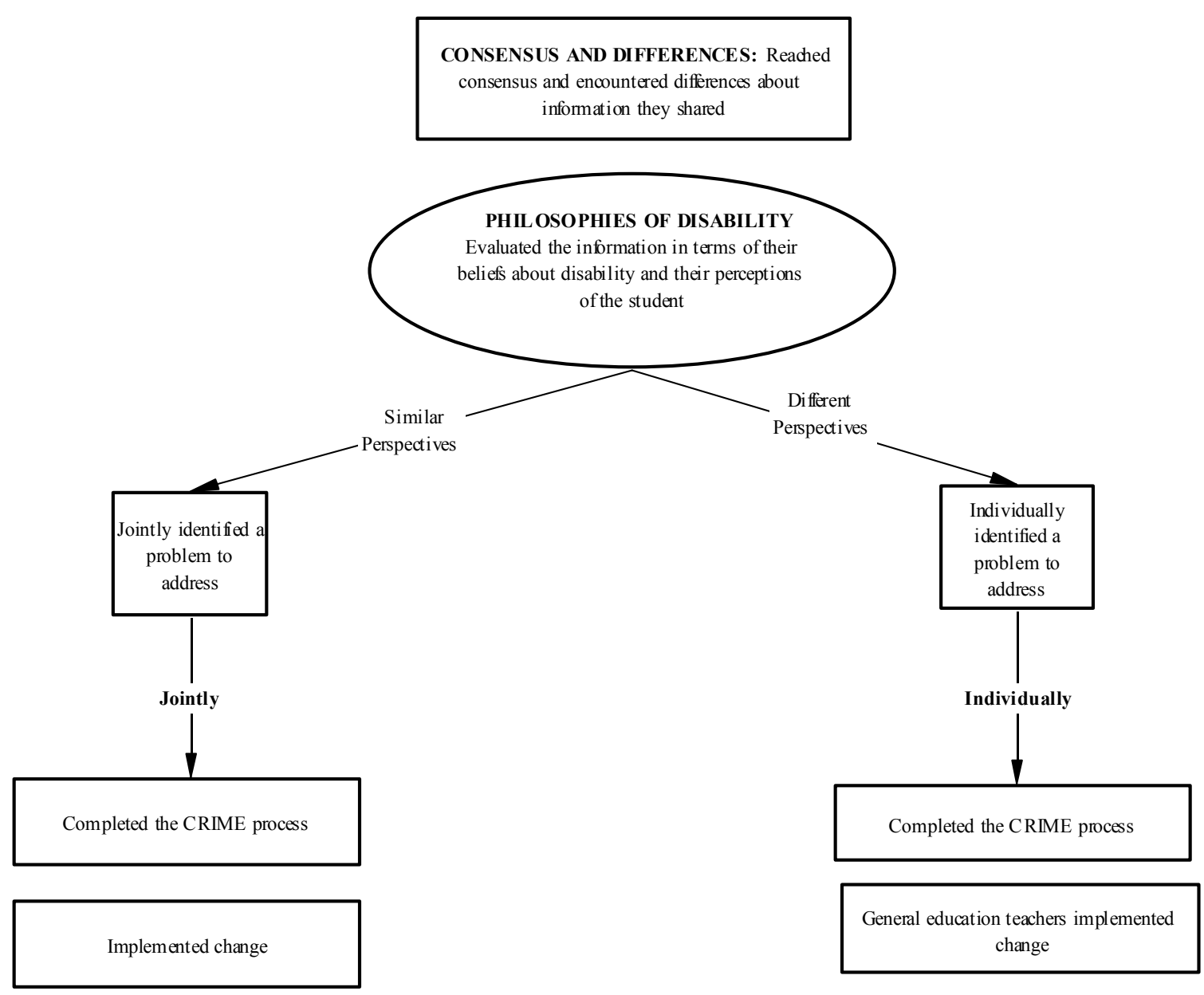

Figure 2. The structure of the CRIME collaboration experience. 


\section{Discussed CRIME Elements}

All of the teachers completed the first two steps of the CRIME process together and they discussed information associated with each step of the process. The first step of the process was to evaluate the general education classroom in terms of the curriculum, rules, instruction, materials, and environment. All of the general education teachers reported that they taught the state core curriculum in their classrooms. In addition to teaching the state core, the teachers specified that they taught Investigations, as the district mandated math program, and they also taught other subjects such as character units, science, social studies, and reading and writing.

Many of the general education teachers reported the same classroom rules. Respect for self, others, and property were classroom rules in most of the general education teachers' classrooms. Other teachers reported the following as rules in their classrooms:

- Complete homework

- Arrive on time

- Don't disturb others

- Use good habits

- Raise hand to talk

After the teachers discussed their classroom rules, they discussed instruction. Unlike rules, where most of the teachers reported having the same or similar rules, the teachers described using a variety of teaching methods to instruct their students. One teacher reported that he incorporated class discussion, group work, and independent work in his instruction. He stated that he did very little lecturing. Another general education 
teacher stated that she used hands on centers for math, literacy, reading, and poetry. Her students completed work at learning centers, and also met on the carpet for large-group instruction. Other teaching methods reported included explicit instruction, modeling, small-group instruction, peer-tutoring, and learning strategy instruction.

For materials and learning environments, the teachers stated that they used grade level materials that were provided by the district or that they created themselves. And, they reported having different environments in their classrooms. Some teachers stated that their classrooms were crowded and busy, and others stated that their classroom were quiet with the students seated in rows or in groups.

After discussing their classroom environments, the teachers reported that they proceeded to the second step of the CRIME process, which was to discuss their students' learning strengths and limitations in terms of their students' skills, learning preferences, and behavior. Appendix M summarizes all of the teachers' comments about their students. As the teachers completed this step of the process all of the teachers reported discussing both their students' strengths and limitations. Although they discussed both strengths and limitations, some of the teachers stated that it was easier for them to pick out their students' limitations than the students' strengths. "I think I was seeing more of his limitations in my classroom." Another teacher stated,

We went through the strengths and limitations and it was really hard actually because it was really easy to see all of the limitations. . . I could pick out some strengths, but it was really hard to think of some of the areas like skills. 


\section{Reached Consensus and Encountered Differences}

As the teachers completed the first two steps of the CRIME process, they reported that they agreed on elements and reached consensus, and that they also encountered differences that required discussion. When the teachers agreed about information they discussed, they did not elaborate on their discussion. They simply stated that they agreed or reached consensus. A general education teacher stated,

We completed a lot of this together--consensus. It wasn't I did this and she did this, it was--it happens for both of us. . I I have bigger groups than she does of course. But she said, yes, that's the way he is in there too.

When the teachers encountered differences, they reported discussing their differing perceptions. All pairs described having differences in knowledge, experience, or in their opinions of either the classroom environment or of the student. For each of the pairs of teachers, their differences surfaced as they discussed specific elements of the CRIME process. For example, the general education teacher from Pair 3 reported that she thought that she and the special education teacher had a different perspective of her instruction. She stated that she did not believe that the special education teacher understood how she instructed her students, and she related,

She didn't understand anything about the attention getters that I use or anything like that. She knew that we used centers, but she didn't know how mine were set up, so all those things were pretty good to help her understand how things function. 
From this discussion, the special education teacher shared that she understood how the general education teacher structured her class, but she also shared that she thought the teacher's instructional style presented problems for the student with disabilities.

The second pair of teachers reported that they had different opinions about their student's behavior. The general education teacher shared that the student got along with his peers, and the special education teacher added that the student bullied other students in her class. As the teachers discussed their different experiences with their student, they agreed that different perspectives of the same student were possible considering that their teaching environments were different.

The teachers from Pair 5 also reported that they each observed different behavior from their student. As the teachers completed the second step of the CRIME process, the general education teacher reported that she told the special education teacher that the student did not work well in groups. Although the special education teacher reported that the student had a slight problem with another student in one of his groups, he had not observed the student having difficulty working in groups. After the general education teacher shared the information, he stated that considering his knowledge of the student, he was not surprised to learn that she had difficulty working in groups, and he accepted the information.

Other teachers reported discussing differences related to their perceptions of class rules. The general education teacher of Pair 6 reported that she told the special education teacher that her rules were posted, and she did not think she had implicit rules. The special education teacher said that she told the general education teacher that she believed there were implicit rules in the general education classroom, and the pair discussed how 
to better explain implicit rules to the student so that the student would know what being in control in the classroom meant. The general education teacher's perception of this discussion was that the discussion of the rules was not a problem for them.

For the fourth pair of teachers, the teachers' different opinions of classroom rules were not discussed or resolved. The general education teacher from Pair 4 related that she believed that the classroom rules in the general education and special education classes were very similar. The special education teacher, on the other hand, reported that she thought that the general education teacher expected her students to understand the rules by $4^{\text {th }}$ grade, and her opinion was the that the class rules in the general education class could be more directly taught to the students. She stated,

I think her feeling is so strong that students should understand by $4^{\text {th }}$ grade what the rules are and how to behave, and she's just kind of upset that he just doesn't pick up. .. He's just not picking up on things that the other kids are trying to cue him to... He doesn't pick up on the rules in here either very easily even though we've gone over them, and I probably need to directly teach them to him again. Although she perceived that they had differing opinions about classroom rules, the special education teacher stated that she did not share her opinions with the general education teacher, and the issue was not discussed or resolved.

The special education teacher from Pair 1 also shared that she did not agree with some of the general education teacher's opinions of the student, and like the special education teacher from Pair 4, did not share her opinions. She explained, I'm not sure that I totally agree that [the classroom environment] is neutral. The student doesn't focus with very much going on, and it's a busy classroom. Not 
that it's out of control or anything, it's just that they've got groups of people wandering and doing things in groups, and that's a little hard for the student to focus in and listen and actually process what's going on when there's that much going on. So, I'm not sure that I would agree that it's neutral. . . I didn't really discuss that with her. I don't know if she would agree, and I didn't want to offend her by making it seem like there was too much going on in her classroom and nobody could concentrate.

\section{Described Philosophical Perspectives}

As discussed above, all of the teachers encountered differences, and four pairs of teachers were able to resolve or reconcile their differences. Two pairs did not discuss or reconcile their differences. Whether or not the teachers resolved, or were able to work around their differences was influenced by their philosophies of learning disabilities, their perceptions of their students' specific challenges, and their perspectives of the instructional needs of students with disabilities. Table 3 presents statements the teachers made that revealed their opinions about disability, their students' disabilities, or instructing students with disabilities.

\section{Defined a Problem}

When the teachers' philosophies were similar or compatible, they agreed about which problems needed to be addressed, and they completed the CRIME process together. On the other hand, when the teachers did not have similar philosophies about students with disabilities and their instructional needs, they did not resolve their differences as a pair, and they did not jointly define a problem to address. 
Table 3

Philosophical Perspectives of Disability or of Instructing Students with Disabilities

\begin{tabular}{|c|c|c|c|}
\hline Pairs & General education & Special education & Similar or different \\
\hline Pair 1 & $\begin{array}{l}\text { "I think she's distracted in here when } \\
\text { she could easily train herself to be } \\
\text { focused. That's not something that } \\
\text { needs to be so catered to. I'm not } \\
\text { really patient with that a lot. But, I } \\
\text { think she can rise to that." }\end{array}$ & $\begin{array}{l}\text { "I don't think her focus is a choice. . . I } \\
\text { don't think she [the general education } \\
\text { teacher] realizes how scattered her } \\
\text { thinking is, so, sometimes I think if you } \\
\text { could get inside in her mind, you } \\
\text { wouldn't be so quick to say you could do } \\
\text { it if you just tried." }\end{array}$ & $\begin{array}{l}\text { Different: The general education } \\
\text { teacher believed that the student's } \\
\text { ability to focus was a matter of } \\
\text { choice, the special education teacher } \\
\text { thought it reflected the student's } \\
\text { scattered thinking and was not a } \\
\text { choice. }\end{array}$ \\
\hline Pair 2 & $\begin{array}{l}\text { "Some of the limitations he puts on } \\
\text { himself. Because of attitudes and } \\
\text { laziness. He's a lot more capable } \\
\text { than what he does." }\end{array}$ & $\begin{array}{l}\text { "He's very forgetful and lazy to an } \\
\text { extent. He doesn't like to have to try on } \\
\text { things, and he'll give up. It's a toss up to } \\
\text { know what it is with [the student] } \\
\text { whether his barrier is his inability to do } \\
\text { it [writing] or his desire to do it." }\end{array}$ & $\begin{array}{l}\text { Similar: Both teachers expressed that } \\
\text { they thought the student limited } \\
\text { himself. However, the special } \\
\text { education teacher also } \\
\text { acknowledged that she didn't know } \\
\text { whether his writing problems were } \\
\text { due to attitude or to an inability to do } \\
\text { the work. }\end{array}$ \\
\hline Pair 3 & $\begin{array}{l}\text { "I don't know that this is really } \\
\text { helping him. I think that maybe a } \\
\text { smaller group setting would be better } \\
\text { for him. But with [this student's] } \\
\text { level of problems and stuff, he can't } \\
\text { be a part of it as much, he's just not } \\
\text { with me." }\end{array}$ & $\begin{array}{l}\text { "He spends most of his day in her class } \\
\text { because that's what the parents want, not } \\
\text { necessarily what he needs. But that's } \\
\text { what the parents have requested so we're } \\
\text { trying to make the environment fit for } \\
\text { him." }\end{array}$ & $\begin{array}{l}\text { Similar: Both teachers believed that } \\
\text { the student's disabilities were such } \\
\text { that he should be in a different } \\
\text { environment, and they were trying to } \\
\text { make the environment fit the } \\
\text { student. }\end{array}$ \\
\hline
\end{tabular}


Pairs

Pair 4 "I think it is human behavior to be able to figure out limitations and downfalls a lot faster than things that are positive. I think that's what teachers look for, what I can fix, how can I help them."
"I think she's expecting things out of him that he's just not prepared to give.

Like the social skills. I think he needs to be directly taught the social skills."
Different: The general education teacher thought it was natural for teachers to look for what can be fixed. The special education teacher said that she thought the general education teacher was expecting things the student wasn't prepared to give.

\section{Similar: Both expressed that the} student has limitations. what others have told me, I think the parents expected that she would be able to be cured. That she would not have these life-long limitations." expectations for the student as for other students except she has different work."

Pair 6 "I expect her to do everything. I expect her to work in groups. . . I give her a little more time if she's not finished."

\author{
"She's fully capable, where she's had \\ great instruction. But just that \\ processing, it's so difficult for her. . . \\ Teachers need to know that not all \\ students learn the same way, and that

Similar: Both teachers expressed that
they expected students with
disabilities to learn, but
acknowledged that this student had
limitations. \\ they expected students with \\ acknowledged that this student had
} just about everything can be taught." 
Table 4 summarizes the problems the teachers defined and whether the teachers agreed about the problems discussed.

When the teachers reported that they agreed about the problem to be addressed, they discussed the problem in terms of "we." A teacher stated,

And so, that's what we want to work on--helping her to overcome that step and teach her how to interact with other students. . We're working on it so that she can work in groups and she can get help not only from the teacher but that she can interact socially with the other students so that she can get the input that she needs.

On the other hand, when the teachers had different philosophical perspectives they did not report jointly agreeing on the problem. Instead, during the research interview, the general education teachers talked about the problems they believed were most important to address and they discussed how they planned to address the problems they identified. The general education teacher from Pair 1 related that she thought the student's poor organizational skills created the most problems for the student.

She believed that the student's lack of organization was particularly problematic in her classroom because of her expectations for the students. She related, I don't know if when we were talking she [the special education teacher] recognized how limiting the organization and sloppiness was. Just because, I expect to say when I want this paper it's where I told them to put it. I don't have the time, nor do I think I should make the time to have 20 kids know where the paper is. 
Table 4

\section{Identified Problems}

\begin{tabular}{|c|c|c|}
\hline Pairs & Problems discussed & Agreed or did not agreed \\
\hline Pair 1 & $\begin{array}{l}\text { The student was disorganized. } \\
\text { The student had difficulty learning concepts and did not } \\
\text { know her math facts. The general education classroom } \\
\text { was not supportive of the student. }\end{array}$ & $\begin{array}{l}\text { Did not identify a problem they both would address. } \\
\text { The general education teacher focused on organization } \\
\text { and the special education teacher focused on math } \\
\text { skills. }\end{array}$ \\
\hline Pair 2 & $\begin{array}{l}\text { The student did not complete class work, or homework. } \\
\text { The student had limited writing skills. }\end{array}$ & $\begin{array}{l}\text { Agreed to address the homework completion issue and } \\
\text { to provide support for writing instruction. }\end{array}$ \\
\hline Pair 3 & $\begin{array}{l}\text { The student's ability to focus attention in the general } \\
\text { education class prevented the student from benefiting } \\
\text { from being included in the class. }\end{array}$ & Agreed to address the attention issue. \\
\hline Pair 4 & $\begin{array}{l}\text { The student's social deficits and disruptive behavior } \\
\text { created problems in the classroom. The student did not } \\
\text { complete homework or class work. The student had poor } \\
\text { writing skills. }\end{array}$ & $\begin{array}{l}\text { Agreed that the student's behavior was a problem, but } \\
\text { did not agree that the homework and in class work was } \\
\text { as important. The general education teacher wanted the } \\
\text { student to complete class work and homework, and the } \\
\text { special education teacher thought the work load should } \\
\text { be cut. The special education teacher was concerned } \\
\text { about the student's writing skills. }\end{array}$ \\
\hline Pair 5 & $\begin{array}{l}\text { The student had difficulty interacting with peers, and had } \\
\text { limited writing and comprehension skills. }\end{array}$ & $\begin{array}{l}\text { Agreed and focused on the writing skills and } \\
\text { comprehension skills. }\end{array}$ \\
\hline Pair 6 & $\begin{array}{l}\text { The student was struggling to learn math concepts and } \\
\text { lacked social skills for appropriately asking for help. }\end{array}$ & Agreed to address both issues. \\
\hline
\end{tabular}


To address this issue, the teacher related that she moved the student's desk closer to hers, and she planned to check the student's binder and desk more frequently.

During the research interview, the general education teacher from Pair 4 did not specifically state that she disagreed with the special education teacher; however, she did describe her perceptions of the student and what she considered to be problematic for the student. The general education teacher identified social skills deficits and work completion problems as the most significant problems the student displayed in her classroom. She commented, "I think the social problems that he's starting to have will get worse if I don't start to help him." She also discussed the work completion problem. I think I was seeing more of his limitations in my class. He would expect to be excused from certain assignments, so he would just keep them in his desk. And then, I would notice a full folder and pull things out and send them home. And then the mother would be calling me and saying why does he have all of these things now? And he's been putting them in his desk instead of bringing them home and doing a little bit to finish things up. That's been a problem.

This teacher decided to model correct social behavior within the context of classroom activities to address the student's social deficits, and she also created a self-management program designed to help the student track his classroom behavior and work completion.

Although the special education teacher from this pair acknowledged that the social skills deficits and work completion issues were problematic, she related that to take stress off of the student, she thought it might be better to cut the student's homework in half. Even though she suggested cutting the student's work in half, she shared that she thought the idea bothered the general education teacher. 
Cutting the assignments down for him really bothers her a lot. She's cut the spelling in half. But, his mother, she's in there part of the time, and his mother really stresses . . . in fact [the general education teacher] has two people coming at her, the student and the mother that are both in tears and upset about how much homework, or how much of this or that. . And I've also met with the parent and the parent has come into me frustrated and wanting me to intervene a little bit in saying it's too much. . . [The general education teacher] gives abundant homework. . . She's trying to reduce it. At the same time, I think she believes this mother needs to expect more out of her child. She has a little bit of those feelings that the mother should tell her child that he can do this rather than stressing herself.

This special education teacher believed that in part, the general education teacher was part of the student's problems because the teacher did not want to reduce the student's assignments, and also because she did not explicitly teach social skills to the student. She compared the general education teacher to another teacher in her school to illustrate how another teacher in her school was more willing to explicitly teach social skills.

I've been working with another $4^{\text {th }}$ grade teacher and she took my social skills book, and copied the pages that had the social skills written out. She's so excited. I think that's what this teacher needs. I think she's needs to access that and to know how to teach them. I think that would help him a lot with all those little behaviors. That would be one way to help with those I think. I think also, if he had a study guide for everything he did, he would feel like he could stay more on 
task. Because it's itemized out, first I do this, then I do this, I'm looking for this and this. And I think it would keep him on task, and I think those behaviors might disappear too.

Just as this special education teacher thought that the general education teacher was part of the problem, the special education teacher from Pair 1 also thought that the general education teacher's teaching style and classroom environment contributed to her student's problems. She stated that she did not think the general education classroom was neutral for the student because she believed that it was too busy and distracting for the student. She also related that she thought that the general education teacher was too hard on the student. This teacher compared the general education teacher to another teacher at her school to illustrate how the other teacher was more responsive to the needs of students with disabilities.

[The other teacher] just came to me and said I really want to work closely, and how would it be if we worked together. . . She really planned around me more. She adapted to the kids. She said, if you'll take these kids during this time, we'll work on our ten-minute math or whatever, but I won't really start the investigation lesson until those guys come back and then you take these two who are getting nothing out of the investigation lesson, and I'll tell you what it is, and you can work with them on their level.

When asked why she had not worked as well with the general education teacher from this collaboration experience, she said,

The general education teacher has never come in and sat down and said what can we do. She's never carved out the time .. I guess that [the other teacher] has. The 
other teacher been really good to work around the low kids. She really teaches to low kids. She's determined that she's going to bring them into the fold. And so, that's what her focus is, and because of that, she's always stopping by to say how's it going, is it working out alright? Here's where we're going to be next week, can we do that? So it's just been easy to work with her.

The differences these teachers described were influenced by their general beliefs about disabilities, and about how to instruct students with disabilities. Because they had divergent views about how to instruct students with disabilities, they did not resolve their differences during their interaction, they did not reach consensus about the problem, and they did not complete the process together.

\section{Planned Accommodations and Adaptations}

Only the teachers who had differences in philosophy did not complete the final step of the process of planning instructional accommodations and adaptations together. All of the other teachers, who had compatible philosophies, jointly planned accommodations and adaptations for their students. The special and general education teachers in Pairs 2, 3, and, 5 reported that they implemented their planned accommodations and adaptations, and Pair 6 stated that they planned to implement the accommodations. The accommodations and adaptations these teachers planned are summarized in Table 5.

The general education teachers from the remaining pairs of teachers, Pairs 1 and 4, completed the last step without consulting the special education teachers. They both reported that they planned and implemented at least one of the accommodations or adaptations that they identified as important for addressing their students' problems. 
Table 5

Planned Accommodations and Adaptations

\begin{tabular}{lll}
\hline Pairs & \multicolumn{1}{c}{ Problem(s) } & Planned accommodations and adaptations \\
\hline Pair 2 & Work completion and & Reduce the amount of homework and provide \\
& poor writing skills. & class time for the student to work on his \\
& Difficulty focusing & Modify the spelling list. Use a microphone during \\
\hline Pair 3 & attention in the general & class, and obtain a computer for the general \\
& education class. & education classroom. \\
& Limited writing and & Provide explicit directions, teach writing skills, \\
& comprehension skills. & and teach comprehension skills. \\
\hline Pair 5 & Social skill deficits and & Teach social skills and touch math. \\
& difficulty &
\end{tabular}

Neither of the special education teachers from these two pairs reported implementing new accommodations or adaptations for their students.

In summary, as the teacher's collaborated to complete the CRIME process, they processed information about the other teacher, the environment, and the student; and, they filtered the information through their philosophies and beliefs about disability, and their perspectives of how to instruct students with disabilities. When the teachers had compatible perspectives, they agreed to address a specific problem, and planned and 
implemented accommodations for their students. When the teachers did not share the same philosophies, they did not discuss or resolve their difference, did not reach consensus about addressing a problem, and did not complete the CRIME process together.

\section{Collaboration Defined}

During the research interview, the teachers described how they completed the CRIME process, which provided information to answer the second research question: How is collaboration defined in this experience? As discussed in the previous section, four out of the six pairs of teachers successfully completed the CRIME process as defined by meeting together and jointly completing all four steps of the process. In order to define collaboration, the researcher examined all of the teachers' interviews for common themes of how they completed the process, and also examined differences between the interviews of teachers who completed the process, and those who did not. All of teachers who completed all four steps of the CRIME process (a) voluntarily agreed to collaborate, (b) contributed in different ways consistent with their knowledge, expertise, and experience, (c) discussed and defined a problem to address, and (d) expressed joint commitment for addressing the problem. The difference between the pairs of teachers who completed the process and those who did not, was the teachers who did not complete the process did not jointly define a problem and did not plan accommodations and adaptations together.

\section{Voluntarily Collaborated}

After each special education teacher agreed to participate in the study, the researcher asked the teacher to recruit a general education teacher to partner with him/her 
to complete the CRIME process. All of the general education teachers voluntarily agreed to complete the process with the special education teachers. Not only did the teachers agree to collaborate using the CRIME model, they all independently scheduled their time to complete the process. The teachers completed the process in the morning before school, after school during their teacher preparation time, and during their lunch time.

\section{Each Contributed Different Information}

As the teachers completed the steps of the CRIME process, their contributions to the process reflected their perception of the process, their expertise and knowledge, and their experience with the student.

Lead the process. Three of the teachers completed their CRIME forms prior to meeting with their special or general education partner, and one general education teacher completed portions of the forms after meeting with the special education teacher. A general education teacher explained why she completed her forms independently, "I did this on my own knowing that she's not ever in my classroom and doesn't know any of these pieces [of information]." The general education teacher who filled out the form after meeting with the special education teacher explained that she and the special education teacher chose to have her complete the form after the meeting to expedite the process.

When the teachers came to the meeting with their forms already filled out, they tended to dominate the process in that they primarily discussed what they had written. In cases where the forms were not filled out prior to meeting, one or the other of the pair tended to take leadership of the process. A special education teacher stated, 
I actually led the discussion. I was asking questions about her classroom. That's the ways we got started, and I think I was starting out with a question format because I was trying to do it in an orderly fashion.

Another teacher assumed leadership because she believed the general education teacher needed her help and stated, "She was like, help me, what do I do... I thought I could address [her concerns] first."

Contributed their expertise. As the special and general education teachers discussed the general education classroom environments and their students' strengths and limitations, their contributions to the process were compatible with their expertise. All of the teachers related that depending upon the step in the process, and the information they were discussing, their contribution to the process was either more significant or less significant than their counterpart, and depended on their knowledge and expertise. For the most part, the general education teachers dominated the first step of the process. The first step involved describing the curriculum, rules, instruction, materials, and the environment of the general education classroom. The general education teachers explained that they dominated the first step because they had more knowledge about their classrooms. "I contributed more [to step one] because it's my classroom, and I'm more familiar with my classroom." Another general education teacher explained, [The special education teacher] didn't know exactly what we use for instruction. I said that we used balanced literacy. . . She didn't understand anything about the attention getters that I use or anything like that. She knew that we used centers, but she didn't know how mine were set up or anything. . I explained about the class rules that I have in my classroom. 
Just as the general education teachers contributed information consistent with their knowledge and experience, the special education teachers contributed information related to specialized instruction. Three of the special education teachers stated that they shared their knowledge of their students' standardized assessment scores with the general education teachers. And, all of the special education teachers suggested accommodations and adaptations consistent with special education training such as teaching social skills, behavior modification plans, peer tutoring, explicit instruction, and task analysis. A special education teacher stated, "[The general education teacher] came up with the idea of cutting spelling words. She wanted to adapt the curriculum so she came up with cutting the spelling words. I came up with the behavior suggestions." Another teacher said,

Because of my background in special education, I'm kind of used to teaching a skill. If a child doesn't have a skill, instead of saying well, you don't have this, and this is what you're doing wrong everyday, and let me give you a list of all the things that I think you could do better on; I just turn around and I teach a skill. So that's just second nature to me to say what is it that she doesn't have, and can the [general education teacher] teach it.

Experience with the student. In addition to contributing different knowledge and expertise to the collaboration experience, the teachers also shared information related to their knowledge and experience with the student. Five of the pairs of teachers had students with disabilities who received instruction in both the special education classroom and in the general education classroom. The sixth pair discussed a student who was fully included in the general education classroom. For the pairs where the students 
with disabilities attended classes in both the resource classroom and in the special education classroom, the special education and general education teachers had different experiences with, and different perceptions of the same student. Examples of differences the teachers discussed are presented in Table 6.

Table 6

Described Differences

\begin{tabular}{ll}
\hline \multicolumn{1}{c}{ Pairs } & \multicolumn{1}{c}{ Experience with the student } \\
\hline Pair 1 & General Education: "The [special education teacher] doesn't see \\
& the social flittering in her isolated classroom." \\
& Special Education: "[The student] focuses in here a little better \\
because I only have three or four of them in here and I can keep her \\
focused."
\end{tabular}

These different perspectives were related to differences between the environments in the special education classes and in the general education classes. One teacher explained why she believed she had a different perspective of her student's skills: 
I had different perspectives because I work with him more one-on-one without the aide right there. I came up with what all of his strengths were, because I work one-on-one with him more. And [the general education teacher] said, 'I really don't know what he can do, what are his strengths?' And I said, well he can sound out the CVC words, he can count to 15 , but he can't do the one-to-one correspondence counting. And she said . ' I had no idea that he could actually do that' because . . a all she sees him with is the aide. And when he comes in here for the hour, I assess him. I know exactly where he is academically. So that's where the differences were.

\section{Defined the Problem}

As the teachers discussed their classroom environments and their different perceptions of their students' learning profiles of strengths and weaknesses, they discussed and defined their areas of greatest concern. To define what they considered to be problems for their students, the process involved describing problems and explaining why specific limitations were most problematic. As discussed in the previous section, the problems the teachers discussed included organization problems, social skills deficits, reading and writing problems, and work completion issues. During the research interview, the teachers explained that as they completed the CRIME process they shared why they believed their students' skill deficits were problematic.

The first pair of teachers related that the student they discussed experienced difficulty being organized. The general education teacher explained why she thought helping the student become organized was critical. 
I think as far as $7^{\text {th }}$ grade goes, they're going to be massive concerns if she can't get more organized. And I think whatever confidence she gains here will be lost if she doesn't become organized. I've seen it with too many kids.

Just as this teacher thought the student's organizational skills were critical for future success, other teachers discussed their students' challenges in terms of what would benefit their students in the future. A general education teacher said, "I want to push him, and get as much out of him as possible, and maybe change his attitudes. If he always thinks that he should be getting less and less, I don't think that that's too beneficial." A special education teacher stated,

I want him to understand that what he wants to do later, if he wants to do construction type work, he has to understand a lot of different things. If he wants to dig a hole, he needs to know measurement. He needs to understand what it is. He doesn't see that correlation. I think that would be a huge lesson for him if he understood that.

Social issues were also concerns for the teachers as expressed in the following quotation:

He does have friends, which is nice, but I think the social problems that he's starting to have will get worse ... He needs to start looking at what everyone else is doing and modify himself to do what everyone else is doing.

One general education teacher related that she believed that her classroom environment created the most significant problem for the student, We've talked about this many times. I think his time would be better spent in the resource room where he would be working with a smaller group. I think that the 
time is wasted and the aide has to spend time giving him rewards trying to stimulate his attention towards me and that kind of thing. Sometimes I think we're failing him in that way.

As the teachers discussed their students' problems, the teachers who completed the process stated that they shared the same perspective of their students' problems. For example, a general education stated, "We both just totally agreed that his main barrier is being able to listen and focus." A teacher from another pair said,

Rules and completing homework. That's a problem because he is forgetful. But, more than that, he's lazy and he has a no care attitude about completing things on time... [the special education teacher] sees that too. Pretty much all of these areas, we both agree.

The teachers who did not complete the process together did not report having the same perspectives of the problems they discussed. One of the general education teachers who did not complete the process with her partner shared that she did not think the special education teacher agreed with her that the student's inability to organize herself was the most significant problem. She said,

They have one little box in their room. There are few things there that they have to keep track of versus in here where there's trillions of things going on. I expect them to be organized. And when I have to sit and wait for the five minutes, or when I keep going and she's behind, and then she's five minutes behind in instruction. . I don't know if that was as highlighted for her. I kept going back to it, and those weren't her frustrations. 


\section{Committed to Address the Problem}

When the teachers jointly defined a problem to address, they completed the CRIME process and planned accommodations and adaptations to address the identified problems. Table 5 (p. 68) presented a summary of the accommodations and adaptations the teachers planned. During the interview, the teachers explained how their pair planned to address the problem. A special education teacher explained, "She agreed to provide explicit directions orally, read directions orally, and get books on her reading level. I would teach reading comprehension, which is part of her goals, and teach how to write a good paragraph.” In explaining the process for addressing the defined problem a general education teacher said, "As we broke things down, it was easiest to say this is what we can do for him in here, and this is what you can take care of for him in there."

Because the other four teachers did not complete the final step of the process together, they did not describe how their pair planned to address their students' problems. Each teacher independently planned how to adjust and adapt his/her instruction or the environment for the student. The teachers did not discuss their plans with their partnered teacher, and one general education teacher stated, "I hope we're close to the same thing on the back," because she did not know what the special education teacher had planned for accommodations and adaptations. The other general education teacher described the interaction when she and the special education teacher discontinued the collaboration process:

Honestly, we were at the end of a meeting, and she was talking to somebody else for quite a while, and then I had to go, so I said add anything else you want to. I don't know if she took my stuff and added on to her sheet anything, or whether or 
not she was going to give it back to me or what. But, the comment was basically, all these things are things that are issues in my classroom, so they're issues that I work on.

For these teachers, each teacher planned accommodations or adaptations that addressed what they considered to be the most significant problem for his/her student, and these four teachers did not report having further discussions or interactions with either the general education or special education teacher between the time they collaborated and when they were interviewed.

Based on the teachers' descriptions of what did and did not happen as they collaborated, the factors that defined collaboration in this experience were (a) voluntarily agreed to collaborate, (b) contributed personal expertise and knowledge, (c) jointly defined an issue or problem to address, and (d) expressed joint committed to address the problem.

\section{Teachers' Perceptions of the CRIME Process}

The third research question was what are general education and special education teachers' perceptions of the CRIME model? During the research interview, the teachers evaluated both the CRIME process and specific elements of the model.

\section{The Overall Process}

All of the teachers stated that they thought the four steps of the process were beneficial. Although they all reported that the process was beneficial, it should be noted that four of the teachers did not complete the process together. However, three of the four teachers from the pairs that did not complete the process together, independently 
completed the last step, and two of the four reported implementing at least one adaptation as a result of the process, which supports their statement about the benefits of the process.

The teachers explained that they thought the overall process was beneficial in terms of interacting with the other teachers and in focusing on the educational needs of their students. One of the general education teachers shared that "being able to work with the resource teacher and knowing what she's doing in her class, and where he's having problems in her class" was beneficial. Some teachers reported that it was helpful to meet together because the other teacher shared information about the student that they did not consider. A general education teacher said,

I first went through and thought of things myself about the student, and then she went back and kind of put in pieces. She was really good with finding strengths. I was really great with finding limitations. She was good to remind me that the student is really willing to please.

In addition to sharing information, a special education teacher related that she believed the collaboration process provided support for the general education teacher. She explained that the teacher was experiencing challenges integrating the student with disabilities in the classroom instruction. She stated,

I think [meeting together] helped her understand that he does have skills, and I think it helped her to understand that it is okay for her to depend on the aide. She's feeling overwhelmed trying to make everybody happy, and she wants to do what's best for the student and what's best for all of her students. I think completing this process helped her understand the whole situation better. I forget that regular education teachers don't have training, and don't know what's 
expected of them. So, it helped her to understand what she can do, that it's okay to depend on the aide and that she had support here.

As this teacher expressed, completing the steps of the process focused the teachers' attention on meeting their students' educational needs. A general education teacher reflected,

This process made me realize that I do a lot already in the classroom. Hopefully it will benefit all of the students and not just him. If I had time, it would be really nice to do this for every child--to be able to realize what their strengths are and what their weaknesses are and how I can help them better, and accommodate their learning style.

A general education teacher said the process helped him to focus on how he could help the student.

This made me think about him a little bit more--where I could improve on my end to help him further. I've dealt with students with similar things, but it just made me concentrate more on him and think about his situation both here and at home. His home life isn't really stable. And it just made me think about him a little bit more.

Although the teachers all stated that they believed the process benefited them, they also related challenges completing the process. All of the teachers said that finding time to meet together was the biggest problem they faced. The teachers reported that they spent between 30 minutes and one hour meeting together, which one teacher thought was too long. The length of the interaction wasn't the only problem the teachers reported. They reported difficulty scheduling time to meet together. One of the special education 
teachers explained why it was difficult for him to find time to collaborate with the general education teacher.

Time is always a difficult thing. Since I'm working with so many teachers, my lunch is usually a working lunch time because I'm checking about this and that and they ask me questions so there's a lot of collaboration time there. One of the barriers is I do not have an extended day contract where the regular education teachers do. So, their day starts with a class at 8:00 a.m. and mine doesn't start until 8:30.

A general education teacher described why it was difficult for her to find time to collaborate.

Time. She was busy. I'm on a couple of committees. In fact, I'm missing a committee meeting right now. . that's been the problem. Just lacking time to be able to get together. She's had IEPs, and I had one yesterday. So, even though I come at 7:00 in the morning and probably leave by 5:00 or 5:30 p.m. It's a long day. No matter what you do, you can't move fast enough to get it all done. All of the teachers agreed that time was a barrier for completing the process. For one set of teachers, their perceptions of the process became a barrier for completing the process. The general education teacher from this pair completed her forms before she met with the special education teacher, and the special education stated that she thought they needed more training to complete the process. She stated, "If you had an in-service where we could watch how people did this model, I think it would be really helpful." She explained that she thought a video model would be helpful because she thought it would 
have been better if she and the general education teacher had completed the process together.

I think it would have been better if we would have sat down and done the whole thing together instead of having it all filled out and just saying all these are okay and do you want to add anything. It would have been more beneficial with the idea that you were going to do the whole thing--you were going to start out at square one here and figure out what is the curriculum in your general education classroom. Of course a lot of this stuff she would have to do anyway, but when we got over to some of these, it would have been better to have started with nothing there and said what are her strengths, what do you see as her strengths, what do I see as her strengths. It isn't necessarily a problem with the model. It's a problem with the way we did it.

\section{CRIME Elements}

When the teachers were asked to evaluate the CRIME model, they reported that they thought the CRIME model was both thorough and redundant. Two of the special education teachers shared that they thought all of the CRIME elements were important to the process. One teacher said,

At first I thought, oh my gosh, this is so detailed, it will take so long. But, as you stop and think about it, it makes you think of things you wouldn't have thought of before. Like the classroom environment. . When you're talking about a specific child, it you want to get individual with him, it is important where the windows are. It's important if these things are going to be distracting to him--you need to 
know where they are. I changed my opinion as I went through it. I think it is important to be that thorough.

In contrast, when asked his opinion of the CRIME model, a general education teacher said,

It's a little redundant. It asks the same questions over. I don't know that I'd go through all of those steps again. Steps 3 and 4 weren't helpful because they were just repeats of steps 1 and 2... Still, Step 4, there's some benefit to step four-getting the accommodations written down.

Besides commenting on specific steps of the process, some teachers discussed problems they had with specific elements of the CRIME model. The element of the CRIME model that the teachers reported having the most challenges understanding or discussing was facilitators. Four teachers reported that they did not fully understand the term and two sets of teachers did not fill in any information on the facilitator column of the third step of the process. A special education teacher explained, "This was an area that was harder for us to understand. We weren't sure on the facilitators for the student. But, we understood what his IEP states, it was easy to see where his barriers were with the curriculum."

Not only did some of the teachers report that they did not understand the term facilitators, four of the teachers stated that they did not understand how to determine their students' facilitators on third step of the process. One of the general education teachers said,

Some of it we weren't quite sure that we understood enhances a facilitator and that kind of stuff. I think we weren't real sure what was expected for neutral for 
the student. We struggle a little bit with that. We had the example, but sometimes even with that we couldn't figure it out. That just took some time, and we both were pressed for time, and that was probably a frustration with it. Maybe if we had done this before, or maybe had gone through it a little more clearly with you and said, 'Okay, what does this mean.' When I looked at it, I didn't realize that I didn't understand that. She was the same way.

In summary, all of the teachers believed that completing the CRIME process was beneficial in terms of meeting with the other teacher, and for planning accommodations and adaptations for their students with disabilities. However, the teachers had different opinions about specific elements of the CRIME model. Some thought all of the elements were necessary for a thorough discussion, and others thought that particular steps and elements were redundant. Some of the teachers had difficulty understanding the term facilitator and knowing how to use the students' strengths to facilitate learning. 


\section{CHAPTER V \\ DISCUSSION}

To fully examine the results of this study, it is important to summarize and discuss the special and general education teachers' descriptions of their experience using the CRIME model (Prater, 2003) to collaboratively plan accommodations and adaptations for students with disabilities included in the general education classroom. A discussion of the results of each research question will be addressed in the following order (a) the nature of the collaborative experience, (b) how collaboration was defined during the experience, and (c) the teachers' perceptions of the CRIME model.

\section{Nature of the Experience}

The teachers in this study had different experiences using the CRIME model to collaboratively plan accommodations and adaptations for students with disabilities. They completed all four steps of the process without any significant difficulties, or they encountered barriers that impacted completing the process together. The factor that significantly influenced the teachers' collaboration experience was their philosophies and beliefs about the nature of disability and also their beliefs about instructing students with disabilities in inclusive classrooms.

\section{Philosophies of Disability}

As the teachers discussed their classroom environments and their students' learning profiles, they revealed their beliefs about the nature of disability. Both special and general education teachers made statements that reflected scientific and post-modern conceptions of disability. Historically, disability has been defined as deviating from the norm. McPhail and Freeman (2005) reviewed the history of how disability has been 
conceptualized and stated that during the first half of the $20^{\text {th }}$ century, educational practices adopted the scientific approach that differences in human functioning were quantitative and individual, and that disability was defined within the normal/abnormal binary of the Western scientific tradition. Educational practices that extended from this perspective aimed at normalizing students with disabilities and were referred to as the medical model (Baglieri \& Knopf, 2004; Fitch, 2003). The medical model is diagnostic and prescriptive. A condition is diagnosed and then a treatment is prescribed.

Another perspective of disability is that disability is natural, acceptable, and ordinary--students are more alike than they are different, and good teachers can teach all students (Will, 1986). With this perspective, diversity is normal, and definitions of disability are a social construction contingent on medical and social attitudes (Baglieri \& Knopf, 2004; Ho, 2004). Because disability can be viewed as a social construction, it can be deconstructed, and instead of emphasizing a student's deficits, educators can focus efforts on understanding how students learn, and can differentiate the classroom instruction to enable all learners to learn (Baglieri \& Knopf, 2004).

Some of the special education and general education teachers in this study expressed the belief that the classroom environment should be adapted to meet the needs of students with disabilities. Although the teachers reported that they had high expectations for their students with disabilities, they acknowledged that their students needed classroom support to facilitate learning. They defined disability as an environmental problem; whereas, other teachers defined disability as a person-centered problem, and adopted the medical model to solve the problem. They focused on how their 
students deviated from their perception of the norm in their classrooms, and they referred to their students as needing to be fixed, or not performing up to their potential.

Central to the collaboration experience was identifying and defining a problem to address, and then determining how to address the problem to enhance student performance. An important aspect of successful collaboration in this experience (in terms of completing all four steps together) was the teachers needed to have the same perspective about disabilities in order to agree about the problem that needed to be addressed. The experience was not impacted by which philosophy individual teachers held about disabilities, but rather by whether the teachers shared the same philosophy of disability. If the teachers had the same philosophy about disabilities they were able to agree about the nature of the problem they were addressing--whether it was a student centered problem such as laziness, or a problem related to the classroom environment such as inadequate classroom support, or a combination of both.

On the other hand, when the teachers' philosophies were not the same--one believing that disability is a student-centered problem and the other believing that disability is natural and should be supported in classroom environments--the teachers did not define a problem to address, and they did not jointly plan classroom accommodations and adaptations.

\section{Planned Accommodations and Adaptations}

The teachers' philosophical beliefs about disability significantly impacted their collaborative experience and also influenced their opinions of classroom accommodations and adaptations. Research indicates that a teacher's philosophy influences whether a teacher is even willing to make accommodations for students with 
learning disabilities. Baker and Zigmond (1995) and Trent (1998) reported that some teachers were philosophically opposed to making any accommodations for students with learning disabilities.

The reason some teachers may be philosophically opposed to making accommodations for students with disabilities is related to how their philosophy of disability influences their perceptions of their classroom practices. Researchers have reported that teachers have different views of classroom culture when students with disabilities are included in a general education classroom. Lieber et al. (1998) studied inclusive preschool programs to examine teachers' beliefs and practices and reported the predominant belief about inclusion meant that every student was a member of the group and the classroom culture, and teachers perceived that their classroom cultures were pluralistic or melting pots. In pluralistic classrooms, teachers believe that the classroom consists of many individuals, and instruction is adapted to meet the needs of various learners. On the other hand, the melting pot view of the classroom is that there is a group norm to be followed, and classroom instruction is geared to meet the needs of the group, rather than individual students.

These two perspectives were evident in this study as the special and general teachers discussed their students' educational needs and suggested specific accommodations and adaptations. Some of the teachers' planned accommodations (providing explicit directions, teaching new skills, altering instruction) reflected a pluralistic view of the classroom in that the teachers acknowledged that their students had unique needs, and they were willing to adapt their environment and/or their instruction to accommodate the students. 
Other teachers planned accommodations that reflected a melting pot view of the classroom environment--in that the accommodations they planned were accommodations that aimed to support their students fitting into the classroom environment rather than accommodations that required them to change and specialize their instruction to meet the needs of their students. For example, one teacher planned to move the student's desk closer to hers to better monitor on-task behavior, another teacher planned to implement a student self-managing system to help the student complete classroom work, and other teachers planned to reduce their students' workload (an accommodation that does not impact instruction).

These accommodations are frequently implemented in general education classrooms. King-Sears and Cummings (1996) reported that general education teachers used self-management techniques to facilitate successful inclusion, and Stockall and Gartin (2002) reported that elementary school teachers modified their students' work by reducing the number of practice problems the students were required to complete. Both of these types of accommodations do not alter daily instruction, which is important to teachers. Bryant et al. (1999) reported that 20 special and general education teachers they surveyed favored accommodations that did not alter the content to be learned, and were not intrusive to their teaching routines, or their time.

As discussed in this section, some of the teachers planned accommodations that put the burden of adapting on the students (the melting-pot perspective), and others planned accommodations that placed the burden for adapting and adjusting on the teacher (the pluralistic perspective). Just as it was important for the teachers to have compatible philosophies about disabilities, it was as important for them to share the same opinions 
about how disabilities should be accommodated in the classroom. When the teachers agreed about how disability should be accommodated in the classroom, they did not encounter problems jointly planning accommodations and adaptations for their students. However, some general education teachers in this study were not willing to individualize instruction for the student with disabilities, which created significant challenges for their special education partners when the special education teachers believed that the classroom environment should be adapted for the student. These teachers did not complete the final step of the CRIME process.

\section{Collaboration Defined}

In research literature, collaboration is defined as a style of interaction between coequal parties who voluntarily engage in shared decision making as they work toward accomplishing common goals. Collaboration, as defined by this experience, was voluntary, each teacher contributed his/her professional expertise and knowledge to the experience, the teachers identified a problem to address, and they expressed commitment for addressing their defined problem.

\section{Voluntary}

An important element of collaboration is voluntary participation (Friend \& Cook, 2003). In this study, all of teachers chose to participate in the study and to complete the CRIME process. They arranged their schedules to complete the process and voluntarily initiated their collaborative interactions.

Parity

As teachers interact in collaborative relationships, parity has been identified as necessary for successful collaboration (Friend \& Cook, 2003). Parity is a situation in 
which each teacher's contributions are equally valued, and each person has equal power to make decisions. Although all of the special and general education teachers contributed to the process, the teachers assumed roles consistent with their training, which meant at times they contributed unequally to the process. The amount of information, and the type of information each teacher brought to the process was not equal. Friend and Cook (2003) stated that if one individual has more valuable knowledge or information than the other, then collaboration cannot occur.

In this regard, the results of this study are different than accepted definitions of collaboration. The teachers did not report contributing equally to the process. They reported contributing more or less than their counterparts, and with the exception of one pair of teachers, the teachers did not report that they had problems with that aspect of the collaborative experience. In fact, they deferred to the other teacher when they perceived that the other teacher had more knowledge, experience, or expertise to address a particular issue, and they expressed respect for the other teachers' contributions, which reflected mutual respect.

Mutual respect may have been a reflection of the teachers' ability to accept professional difference in collaborative interactions. As the teachers shared different experiences and knowledge, all of the teachers encountered differences. For the teachers who completed the process, discussing and resolving differences was not a problem. They acknowledged that they had different knowledge and experience, and stated that they benefited from interacting with the other teacher. Differences can be viewed as potentially beneficial in collaborative relationships if the teachers work through their differences and can leverage each other's strengths. Salend and Johansen (1997) reported 
that when the teachers they studied worked through their differences, they came to appreciate the value of their differences, and leveraged their individual strengths as they taught in the classroom. Trent et al. (2003) reported that after two years of co-teaching, both teachers they observed became better teachers as they integrated their styles and expertise. Complete equality in this experience was not as important for successful collaboration as was mutual respect.

\section{Common Goals}

Only when differences involved philosophical beliefs did the teachers encounter differences they did not resolve. Pugach and Johnson (2002) described different philosophies between teachers as a source of difficulty in collaborative relationships, and Salend and Johansen (1997) reported that special education and general education teachers who co-taught had philosophical differences surface in their relationships. Philosophical compatibility is not mentioned in literature as an element of collaboration. Yet, it was critical for successful collaboration in this experience. As discussed in the previous section, the teachers' philosophical compatibility directly impacted identifying and defining a problem to address, and this collaboration experience hinged on whether the teachers successfully identified and defined a problem.

The CRIME model is not specifically a problem solving process, but the experience became a problem solving process as the teachers had to define a problem to address before they could plan accommodations and adaptations for their students. Defining a problem is the first step in problem solving processes (Davidson \& Wood, 2004; Friend \& Cook, 2003). Friend and Cook (2003) stated that problem identification is the most critical step in problem solving. In this experience, identifying a problem to 
solve was not only critical for problem solving processes, it was also critical for successful collaboration to occur, and was more important than having at least one common goal.

Friend and Cook (2003) stated that teachers should share at least one common goal in order to successfully collaborate. The teachers who participated in this study all were committed to educating their students and expressed a desire to help their students improve academic achievement. For this project, the teachers also shared the goal of completing the CRIME process to plan instructional accommodations and adaptations. Although all of the teachers had the same general goals, they did not all share the same philosophies about educating children with disabilities, and the experience was defined more around philosophical compatibility then sharing common goals. It could be argued that the defined problem became a common goal for the teachers. Which, in essence it did become a common goal. However, it became a goal that emerged from the process, and it did not define the process.

\section{Shared Decision Making}

The special education and general education teachers decided which accommodations they would implement in their classrooms. For the teachers who completed the process, some jointly decided how they would accommodate their students' educational needs. Other teachers decided for themselves how they would address their students' needs, and their counterparts agreed with and accepted their decisions. In explaining the importance of sharing responsibility for participating and making decisions, Friend and Cook (2003) stated that when individuals collaborate, they should have equal participation in the critical decision making involved in the activity-- 
they do not necessarily have to equally participate in implementing tasks, but they should equally contribute to the decision making processes.

Teachers in this study, who completed the process together, did not object to the other teacher independently deciding to implement specific accommodations. They respected their partners' ability to decide how to address the problem in their own classroom environment. What was important was that both teachers were committed to addressing the problem they identified. When they both expressed commitment for addressing the problem, they both planned accommodations that supported the student in their individual environments. On the other hand, when the teachers did not jointly define a problem to address, they did not express joint commitment and responsibility for addressing the problem, and they planned accommodations and adaptations without consulting with or reviewing their plans with the other teacher.

\section{Perceptions of the CRIME Model}

After completing the CRIME process, all of the teachers reported that the process was beneficial in terms of evaluating the support they provided for their students, and in helping them to better understand their students' educational needs. When teachers have a clearer understanding of their students' needs, they are better able to plan appropriate education. It is particularly important for teachers to determine students' educational needs to develop educational plans that are student driven (Marston, 1996). Not only is it important to determine a student's educational needs, teachers also need to evaluate their classroom practices as to whether they are implementing instructional strategies that optimize learning. Amato (1996) reported that when elementary school teachers evaluated the performance of their students, identified which students needed 
instructional support, and then evaluated and implemented effective instructional practices, the number of referrals to special education decreased.

\section{Challenges}

The steps of the CRIME process that focused the teachers' discussions on their students' needs were the second and third steps--evaluate the student's strengths and limitations, and compare classroom practices with the student's strengths and limitations. For the most part, the teachers reported that the entire CRIME process was easy to learn and to complete. However, some of the teachers stated that they did not understand the term facilitator used in the third step of the process, and they did not understand how their students' strengths could be viewed as an asset for helping the students experience success with the curriculum, rules, instruction, materials, and in the classroom environment.

The difficulty the teachers reported understanding the term facilitator and completing the third step could be due to not understanding how various intellectual strengths can be used to foster development among students with disabilities, rather than to not understanding the term. Researchers are beginning to document the ways in which the intellectual strengths of students with disabilities can be leveraged to foster learning and development (McPhail \& Freeman, 2005). This is a different perspective from how disabilities have historically been viewed. In the past, a student with disabilities was diagnosed and interventions were prescribed to normalize the child. The historical perspective of disability was a deficit-driven model where the student's deficits were the focus of instruction. 
In order for teachers to understand that students with disabilities have strengths as well as limitations, they will have to shift their paradigms from thinking only in terms of learning deficits to also looking for potential. Both special and general education teachers reported that it was easier to see their students' limitations than to identify their students' strengths, which could explain why the teachers reported having difficulty with the third step of the process.

Beyond the specific steps, or elements of the CRIME model, all of the teachers reported that finding time to complete the process was difficult. This is consistent with findings from other research studies. Numerous other studies have reported that scheduling time is a barrier for effective collaboration (Kamens et al., 2003; Klinger \& Vaughn, 2002; Malone, Gallagher, \& Long, 2001; Scruggs \& Mastropieri, 1996; Trent, 1998; Weiss \& Lloyd, 2002). The teachers surveyed by Kamens et al. (2003) stated that they needed administrative support to help them find time to collaborate.

\section{Benefits}

When teachers scheduled time to collaborate, they reported benefiting from collaborative interactions (Burnstein et al., 2004; Fisher \& Frey, 2001; Trent et al., 2003). Researchers have found that when teachers effectively collaborate, they acquire new skills, implement effective instructional strategies, and feel supported in their professional endeavors. Both special education and general education teachers reported that they benefited from collaborating. Primarily, they related that their companion teacher had knowledge and information they lacked and they appreciated learning more about their student, and also appreciated the support the other teacher offered. 


\section{Implications for Practice}

Including students with disabilities in general education classrooms becomes inclusive education when students with disabilities benefit from their education. Effective inclusion depends on effective collaboration and teachers need support to effectively collaborate. First, teachers need administrative support for collaboration. Although these teachers taught in a school district that promoted professional collaboration by scheduling teacher collaboration time one afternoon a week, the teachers related that the designated collaboration time was often used for faculty meetings, and they struggled to find time to meet. Administrators can support collaborative planning by freeing up teachers' schedules to allow them time to collaborate (Burnstein et al., 2004).

Not all teachers share common philosophies concerning students with disabilities. Pre-service and in-service training should equip teachers with skills for addressing philosophical differences. In this study, the teachers respected their counterparts' knowledge and expertise. But, when the teachers encountered philosophical differences, they did not demonstrate communication skills that enabled them to effectively resolve philosophical differences in a way that allowed them to work together. Also, because there was no administrative involvement in the process, and the teachers voluntarily agreed to use the CRIME model (Prater, 2003) to collaboratively plan, the teachers did not have external motivation for working through their philosophical differences. When the process did not work well for them, they simply abandoned the process. Rather than expecting that teachers will voluntarily initiate and follow through with collaborative planning, teacher may need impetus for school authorities to engage in meaningful collaboration (Burnstein et al, 2004). 
If administrators do become involved in directing collaborative processes in their schools, the processes do not have to be complex. Teachers can learn to use specific models with relatively little training. The researcher did not spend extensive time training the teachers to use the CRIME model. Essentially, the teachers used the completed example to help them understand the process. The majority of the teachers stated that the example was adequate training, and they thought that following a specific process was more beneficial than unstructured meetings. To support collaboration, administrators should not only support teachers by ensuring that they have time to collaborate, they should also direct collaboration efforts by promoting specific models (e.g., Beloin, 1998; Hunt et al., 2003; Prater, 2003; Salisbury, 1997).

Even when collaborative planning takes place, teachers may not plan meaningful accommodations and adaptations. Researchers have shown that using direct instruction methods, teaching students mnemonic and comprehension strategies, and implementing behavior modification programs produces the largest effects for students with disabilities (Forness, 2001). Although some of the teachers discussed accommodations and adaptations that included effective strategies, they also planned accommodations and adaptations that were convenient for them to implement such as reducing their students' workload, and such accommodations may not yield positive academic results.

Pre-service and in-service training should focus on how to plan accommodations that not only enhance education, teachers should also be taught how to plan accommodations and adaptations that capitalize on their students' strengths. In this study, it was easy for both special education and general education teachers to identify their students' limitations and to conceptualize their students as deficient. It was harder for the 
teachers to describe their students' strengths, and some of the teachers did not know how to plan accommodations and adaptations that leveraged their students' strengths. Teacher training programs should address this issue. Training programs can balance teaching teachers how to address learning deficits with teaching teachers how to support learning potential (McPhail \& Freeman, 2005).

Finally, it is difficult for teachers to collaboratively plan effective accommodations and adaptations if they lack skills for solving problems. Educating students with disabilities is essentially a problem solving process. Students with disabilities often experience difficulty learning, and when teachers collaborate, they should identify the nature of their students' struggles and then plan supports that will enable their students to learn. Problem solving skills are an important aspect of educating students with disabilities. As evidenced in this study, identifying the problem to be solved can be a challenging aspect of collaboration. Pre-service and in-service training should equip teachers with skills for clearly defining problems. Only when teachers can clearly define problems can they plan appropriate solutions.

\section{Limitations of the Study}

This research study had some limitations. Each of the teachers who participated in this study taught elementary school in a large school district in Utah. They were a small sample of teachers from this school district and did not necessarily represent all of the special- and general-education elementary school teachers from this district. Only those who met the selection criteria were selected to participate, and all of the general education teachers were invited to participate by the special education teachers at their schools. The comments of the special education and general education teachers contribute 
to the body of research on collaboration. However, because the special education teachers invited the general education teachers to participate, their comments, opinions, and perceptions, should be understood within the context that they were selected by the special education teachers.

Also, the researcher did not observe the teachers as they completed the CRIME process. The researcher interviewed the teachers about their experience, and there is the possibility that the teachers' perceptions of the experience may not have been what actually occurred. The purpose of this study was to describe teachers' perceptions of the collaborative experience, and the research interview provided an opportunity for the teachers to describe their perceptions of what occurred when they planned accommodations and adaptations for their students with disabilities.

A specific model for collaborative planning was used in this research study. There are many different types of collaborative interactions and the results of this study should be interpreted according to the parameters of the study.

\section{Future Research}

This research study described elementary school teachers' perceptions of their experience using the CRIME model to plan accommodations and adaptations for students with disabilities. Future research could investigate secondary-education teachers' perceptions of the model. It would be interesting to investigate if secondary teachers have similar or different experiences with the model. Also, this study involved teachers from one school district. Other studies could include teachers from a number of different school districts. A follow-up study could involve video-taping the teachers' collaborative interactions when they do not use a specific model. Analyzing their actual interactions in 
a more naturalistic environment could provide additional information about the dynamics of collaborative planning.

Although the teachers were not asked to implement their planned accommodations and adaptations, an extension of this study would be to investigate the effect of the planned accommodations and adaptations on student performance. The teachers from this study had positive perceptions of the effects of their implemented accommodations. It would be important to gather data on the actual effects of the implemented accommodations and adaptations. Also, it would be important to study the effect of specific types of planned research-validated accommodations on student achievement. Some of the teachers in this study reported planning accommodations such as reducing the students' work load, which may or may not enhance academic performance. Future single-subject design research studies could investigate whether collaborative planning, that involves implementing research-validated accommodations, improves student academic performance.

This study described a specific type of collaborative interaction. When teachers are involved with educating students with disabilities, there are many different types of planning interactions along the continuum of consultation, collaboration, and co-teaching. Future research studies could investigate the nature of different collaborative interactions. It would be helpful to study various interactions to see if the results of this study are consistent with results of other types of collaborative experiences. 


\section{REFERENCES}

Amato, C. (1996). Freedom Elementary School and its community: An approach to school-linked service integration. Remedial and Special Education, 17, 303-309.

Anastas, J. W. (2004). Quality in qualitative evaluation: Issues and possible answers. Research on Social Work Practice, 14(1), 57-65.

Baglieri, S., \& Knoph, J.H. (2004). Normalizing difference in inclusive teaching. Journal of Learning Disabilities, 37, 525-529.

Baker, J. M., \& Zigmond, N. (1995). The meaning and practice of inclusion for students with learning disabilities: Themes and implications from the five cases. Journal of Special Education, 29, 163-180.

Bassett, D. S., Jackson, L., Ferrell, K. A., Luckner, J., Patricia, J. H., Bunsen, T. D., et al. (1996). Multiple perspectives on inclusive education: Reflections of a university faculty. Teacher Education and Special Education, 19, 355-386.

Beloin, K. S. (1998). Strategies for developing inclusive practices in small, rural schools. Special Education Quarterly, 17, 12-20.

Board of Education v. Rowley, 458 U.W. 176 (1982). Retrieved August 16, 2005 from: http://caselaw.lp.findlaw.com/scripts/getcase.pl?court=us\&vol=458\&invol=176

Boyle, E. A., Rosenberg, M. S., Connelly, V. J., Washburn, S. G., Brincherhoff, L. C., \& Banerjee, M. (2003). Effects of audio texts on the acquisition of secondary-level content by students with mild disabilities. Learning Disability Quarterly, 23, 203214.

Brice A., \& Miller, R. F. (2000). Case studies in inclusion: What works, what doesn't. Communication Disorders Quarterly, 21, 237-241. 
Brown v. Board of Education, 349 U.S. 294 (1955).

Bryant, R., Dean, M., Elrod, G. F., \& Blackbourn, J. M. (1999). Rural general education teachers' opinions of adaptations for inclusive classrooms: A renewed call for dual licensure. Rural Special Education Quarterly, 18(1), 5-11.

Burnstein, N., Sears, S., Wilcoxen, A., Cabello, B., \& Spagna, M. (2004). Moving toward inclusive practices. Remedial and Special Education, 25, 104-116.

Creswell, J. W. (1998). Qualitative inquiry and research design: Choosing among five traditions. Thousand Oaks, CA: Sage.

Coben, S. S., Thomas, C. C., Sattler, R. O., \& Morsink, C.V. (1997). Meeting the challenge of consultation and collaboration: Developing interaction teams. Journal of Learning Disabilities, 30, 427-432.

Daniel R. R. v. State Board of Education 874 F.2d 1036 (5 $\left.5^{\text {th }} 1989\right)$.

Dansforth, S. (1997). On what basis hope? Modern progress and postmodern possibilities. In M. Byrnes (Ed.), Taking Sides: Clashing views on controversial issues in special education (2 ${ }^{\text {nd }}$ ed., pp. 4-13). Dubuque, IA: McGrawHill/Duskin.

Davidson, J., \& Wood, C. (2004). A conflict resolution model. Theory Into Practice, 43, 6-13.

deBettencourt, L.U. (1999). General educators' attitudes toward students with mild disabilities and their use of instructional strategies: Implications for training. Remedial and Special Education, 20(1), 27-35. 
Deschenes, C., Ebeling, D. G., \& Sprague, J. (1994). Adapting curriculum and instruction in inclusive classrooms: A teacher's desk reference. Bloomington, IN: The Center for School and Community Integration Institution for the Study of Developmental Disabilities.

Edmunds, A. (2000). Teachers' perceived needs to become more effective inclusion practitioners: A single school study. Exceptionality Education Canada, 10(3), 323.

Education for All Handicapped Children 1975, 20 U.S.C. $§ 1401$ et. seq.

Fisher, D., \& Frey, N. (2001). Access to the core curriculum: Critical ingredients for student success. Remedial and Special Education, 22, 148-57.

Fitch, E. F. (2002) Disability and inclusion: From labeling deviance to social valuing. Educational Theory, 52, 463-477.

Fletcher, T.V., Bos, C. S., \& Johnson, L. M. (1999). Accommodating English language learners with language and learning disabilities in bilingual education classrooms. Learning Disabilities Research and Practice, 14(2), 80-91.

Foley, R. M., \& Mundschenk, N. A. (1997a). Collaboration activities and competencies of secondary school special educators: A national survey. Teacher Education and Special Education, 20, 47-60.

Foley, R. M., \& Mundschenk, N. A. (1997b). Secondary school general educators' collaboration competencies and collaboration activities with general educators, special educators, and community service providers: A status report. Journal of Research and Development in Education, 30(3), 154-166. 
Forness, S. R. (2001). Special education and related services: What have we learned from meta-analysis? Exceptionality, 9, 185-197.

Fox, N. E., \& Ysseldyke, J. E. (1997). Implementing inclusion at the middle school level: Lessons from a negative example. Exceptional Children, 64, 81-98.

Friend, M., \& Cook, L. (2003). Interactions: Collaboration skills for school professionals. ( $4^{\text {th }}$ ed.). Boston: Allyn \& Bacon.

Gallagher, J. J. (1994). The pull of societal forces on special education. The Journal of Special Education, 27, 521-530.

Goals 2000: Educate America Act of 1994, U.S. Congress, $2^{\text {nd }}$ Session.

Hallahan, D. P. (2005). We need more intensive instruction. In M. Byrnes (Ed.), Taking Sides: Clashing views on controversial issues in special education $\left(2^{\text {nd }}\right.$ ed., pp. 190-192). Dubuque, IA: McGraw-Hill/Duskin.

Hatch, J. A. (2002). Doing qualitative research in education settings. Albany: State University of New York Press.

Heflin, L. J., \& Bullock, L. M. (1999). Inclusion of students with emotional/behavioral disorders: A survey of teachers in general and special education. Preventing School Failure, 43(3), 103-111.

Ho, A. (2004). To be labeled, or not to be labeled: That is the question. British Journal of Learning Disabilities, 32, 86-92.

Hunt, P., Soto, G., Maier, J., \& Doering, K. (2003). Collaborative pairing to support students at risk and students with severe disabilities in general education classrooms. Exceptional Children, 69, 315-332.

Improving America's Schools Act, 1994, U.S. Congress, $2^{\text {nd }}$ Session. 
Individuals with Disabilities Education Act Amendments of 1997, 20 U.S.C. Section 1400 et seq.

Individuals with Disabilities Education Improvement Act of 2004, 20 U.S. C. $§ 1401$ 1485.

Johnson, E. S. (2000). The effects of accommodations on performance assessments. Remedial and Special Education, 21, 261-267.

Kamens, M., W., Loprete, S. J., \& Slostad, F. A. (2003). Inclusive classrooms: What practicing teachers want to know. Action in Teacher Education, 25, 20-26.

Kauffman, J.M. (2005). Commentary: Today's special education message for tomorrow. In M. Byrnes (Ed.), Taking Sides: Clashing views on controversial issues in special education (2 ${ }^{\text {nd }}$ ed., pp. 14-23). Dubuque, IA: McGraw-Hill/Duskin.

Kavale, K. A., \& Forness, S. A. (2000). History, rhetoric and reality: Analysis of the inclusion debate. Remedial and Special Education, 21, 279-296.

King-Sears, M. E. (1997). Best academic practices for inclusive classrooms. Focus on Exceptional Children, 29(7), 1-22.

King-Sears, M. E., \& Cummings, C. S. (1996). Inclusive practices of classroom teachers. Remedial and Special Education, 17, 217- 225.

Klinger, J. K., \& Vaughn, S. (2002). The changing roles and responsibilities of an LD specialist. Learning Disability Quarterly, 25, 19-31.

Kvale, S. (1996). Interviews: An introduction to qualitative research interviewing. Thousand Oaks, CA: Sage. 
Lieber, J., Capell, K., Sandall, S. R., Woldberg, P., Horn, E., \& Beckman, P. (1998). Inclusive preschool programs: Teachers' beliefs and practices. Early Childhood Research Quarterly, 13(1), 87-105.

Lipsky, D. K., \& Gartner, A. (2005). Taking inclusion into the future. In M. Byrnes (Ed.), Taking Sides: Clashing views on controversial issues in special education $\left(2^{\text {nd }}\right.$ ed., pp. 184-189). Dubuque, IA: McGraw-Hill/Duskin.

Malone, D. M., Gallagher, P. A., \& Long, S. R. (2001). General education teachers' attitudes and perceptions of teamwork supporting children with developmental concerns. Early Education and Development, 12, 577-591.

Marston, D. (1996). A comparison of inclusion only, pull-out only, and combined service models for students with disabilities. The Journal of Special Education, 30, 121132.

Maxwell, J. A. (2005). Qualitative research design. Thousand Oaks, CA: Sage.

McPhail, J. C., \& Freeman, J. G. (2005). Beyond prejudice: Thinking toward genuine inclusion. Learning Disabilities Research and Practice, 20, 254-267.

Mercer, C. D., \& Mercer, A. R. (2005). Teaching students with learning problems. Upper Saddle River, NJ: Pearson Education.

Mills v. Board of Education, 348, F. Supp. 866 (D.D.C. 1972).

Munk, D. D., \& Bursuck, W. D. (1998). Report card grading adaptations for students with disabilities: Types and acceptability. Intervention in School and Clinic, 33, 306-308. 
National Center of Education Statistics. (2002). Contexts of Elementary and Secondary Education (Indicator 28). Retrieved November 15, 2004 from: http://nces.ed.gov/programs/coe/2002/section4/indicator28.asp

No Child Left Behind. (2002). 20 U.S.C. sec. 6301 et seq.

Oberti v. Board of Education 995 F.2d 1204 ( $3^{\text {rd }}$ Cir. 1993).

Passe, J., \& Beattie, J. (1994). Social studies instruction for students with mild disabilities: A progress report. Remedial and Special Education, 14, 227-233. Pennsylvania Association of Retarded Children v. Pennsylvania, 334 F. Supp. 1257 (E.D.Pa. 1971).

Polloway, E. A., \& Bursuck, W. D. (1996). Treatment acceptability: Determining appropriate interventions within inclusive classrooms. Intervention in School and Clinic, 31, 133-144.

Prater, M. A. (2003). She will succeed: Strategies for success in inclusive classrooms. TEACHING Exceptional Children, 35(5), 58-64.

Prater, M. A. (in press). Teaching strategies for students with mild/moderate disabilities. Boston: Allyn \& Bacon.

Pugach, M. C., \& Johnson, L. J. (2002). Collaborative practitioners, collaborative schools. ( $2^{\text {nd }}$ ed.). Denver, CO: Love Publishing.

Roberts, G. J. (2001). General and special educators' attitudes toward inclusion of students with mild/moderate disabilities. Ann Arbor, MI: ProQuest Information and Learning.

Roncker v. Walter 700 F.2d 1058 (6 ${ }^{\text {th }}$ Cir. 1983). 
Rothstein, L.F. (2000). Special Education Law. ( $3^{\text {rd }}$ ed.). New York: Addison Wesley Longman.

Salend, S. J., \& Johansen, M. (1997). Cooperative teaching. Remedial and Special Education, 18, 3-12.

Salisbury, C. L., Evans, I. M., \& Palambaro, M. M. (1997). Collaborative problemsolving to promote the inclusion of young children with significant disabilities in primary grades. Exceptional Children, 63, 195-209.

Schumm, J. S., \& Vaughn, S. (1995). Meaningful professional development in accommodating students with disabilities: Lessons learned. Remedial and Special Education, 16, 344-353.

Scruggs, T. E., \& Mastropieri, M. A. (1996). Teacher perceptions of mainstreaming/inclusion 1958-1995. A research synthesis. Exceptional Children, $63,59-74$.

Shriner, J.G. (2000). Legal perspectives on school outcomes assessment for students with disabilities. The Journal of Special Education, 33, 232-239.

Stainback, W., \& Stainback, S. (1991). Rationale for integration and restructuring: A synopsis. In J.W. Lloyd, A.C. Repp, \& N.N. Singh (Eds.), The Regular Education Initiative: Alternative perspectives on concepts, issues, and models (pp. 225-239). Sycamore, IL: Sycamore.

Stockall, N., \& Gartin, B. (2002). The nature of inclusion in a blue ribbon school: A revelatory case. Exceptionality, 10, 171-188. 
Tomlinson, C. A. (2001). How to differentiate instruction in mixed-ability classrooms ( $2^{\text {nd }}$ ed.). Alexndria, VA: Association for Supervision and Curriculum Development.

Trent, S. C. (1998). False starts and other dilemmas of a secondary general education collaborative teacher: A case study. Journal of Learning Disabilities, 31, 503-513.

Trent, S. C., Driver, B. L., Wood, M. H., Parrott, P. S., Martin, T. F., \& Smith, W. G. (2003). Creating and sustaining a special education/general education partnership: A story of change and uncertainty. Teaching and Teacher Education, 19, 203219.

Utah State Office of Education. (2003). Superintendent's annual report: Statistical and Financial data tables 2003-04. Retrieved April 2, 2005 from: http://www.usoe.k12.ut.us/data/ar/2003/demographics03.htm

Vaughn, S., \& Schumm, J. S. (1995). Responsible inclusion for students with learning disabilities. Journal of Learning Disabilities, 28, 264-270.

Weiss, M. P., \& Lloyd, J. W. (2002). Congruence between roles and actions of secondary special educators in co-taught and special education settings. The Journal of Special Education, 36(2), 58-68.

Will, M. (1986). Educating children with learning problems: A shared responsibility. Washington, D.C.: Office of Special Education and Rehabilitation Services, U.S. Department of Education.

Zigmond, N, \& Baker, J. M. (1996). Full inclusion for students with learning disabilities: Too much of a good thing? Theory into Practice, 35, 26-34. 


\section{APPENDICES}

Appendix A

\section{Personal Experience Memo}

Although we suspected Ryan might have learning disabilities, when the psychologist suggested that he be placed in a program for developmentally disabled children, I was devastated. I was also confused. In the same meeting that the psychologist shared his recommendations, the learning specialist shared that she expected that he might some day be classified gifted because she rarely saw some of the abilities he displayed. In my confusion, I decided that I would try to tap into Ryan's abilities rather than focus on his obvious limitations.

When Ryan was in $2^{\text {nd }}$ grade, he experienced difficulty learning $2^{\text {nd }}$ grade math facts. His classroom teacher suggested that I talk with the special education teacher to see if Ryan might benefit from instruction in a special education class. When I visited the classroom, instead of feeling encouraged that the teacher would help, I was dismayed to observe a classroom environment that I perceived lacked educational substance. During one hour of instruction, the third grade students stretched, listened to music, and drew pictures. The only academic activity they engaged in was writing one sentence. I decided Ryan would be served better in a general education class, and from that point forward, I provided the support he needed to access general education curriculum.

As Ryan has progressed in school, some of his teachers have incorporated practices in their classrooms that have supported learning, and others have adopted practices that have created barriers and limited Ryan's ability to learn. For example, his $9^{\text {th }}$ grade earth science teacher provided study guides for each textbook chapter, and for 
chapter tests. This practice helped Ryan focus his attention on relevant information, and enabled him to learn the curriculum. On the other hand, his foods teacher did not have a classroom textbook. Because Ryan processes information slowly, he often was unable to complete class work during class, and because there was no classroom textbook or note packets to take home, he often struggled to access information that would enable him to complete assignments.

My experience having a child with disabilities has significantly shaped my opinions about inclusion, about children with disabilities, about their ability to learn, and about teaching children with disabilities. I believe that with appropriate support and effective instruction, children with mild/moderate disabilities can learn basic academic skills.

In addition to having the perspective of a mother, I am also a graduate student. As a graduate student I have had opportunities to train special education teachers, and to write about teaching students with disabilities. For three years I have mentored and supervised special education undergraduate and licensure students as they have taught students with disabilities during BYU's Summer Mild/Moderate Practicum. I have also coauthored three chapters about accommodations and teaching strategies (Prater, in press). One of the chapters discusses the CRIME model. 


\section{Appendix B}

\section{Consent to be a Research Participant}

\section{Introduction}

This research study is being conducted by Nari Carter. The purpose of this study is to describe teachers' perceptions of the CRIME (Curriculum, Rules, Instruction, Materials, Environment) model. You have been selected to participate because you are either a special education or a general education teacher teaching at a public elementary school. Procedures

As part of this study, you will be taught the CRIME model, and in conjunction with either a special or general education teacher, you will complete forms that take you through the steps of the model. This process should take approximately 30 to 45 minutes to complete. After completing the collaboration process, you will be interviewed about your experience. The interview will consist of open-ended questions and should take 30 to 40 minutes to complete. Your interviews will be tape recorded and then transcribed.

\section{Risks/Discomforts}

There are minimal risks associated with participating in this study. If you feel any personal discomfort answering questions, or if participating consumes more time than anticipated, the researcher will accommodate your needs, and make adjustments to minimize your discomfort.

Benefits

Completing the CRIME process may assist you in planning instructional adaptations and accommodations for your students with disabilities, and may facilitate professional collaboration. 


\section{Confidentiality}

All information provided will remain confidential and will be reported in conjunction with information obtained from other participants. Any information that may identify a participant will be deleted, or changed to protect the identity of research participants.

\section{Compensation}

Each participant will receive a $\$ 10.00$ gift certificate from Wal-Mart for participating in this research study. The gift certificate will be given at the conclusion of the interview. Participation

Participation in this research study is voluntary. You have the right to withdraw at any time.

\section{Questions}

If you have any questions regarding this study, contact Nari Carter at $472-9788$ or by email at narij@comcast.net. . If you have any questions you are not comfortable asking Nari Carter, please contact Dr. Mary Anne Prater or Dr. Aaron Jackson. Dr. Prater can be contacted by phone at (801) 422-1592, or by e-mail at Prater@byu.edu. Dr. Jackson can be contacted at (801) 422-8031, or by e-mail at aaron_jackson@byu.edu.

I have read, understood, and received a copy of the above consent form and agree to participate in this research study.

Name of participant:

Date:

Signature: 
Appendix C

Confidential Demographic Questionnaire

1. Name

2. Teaching area (general education or special education)

3. List your teaching certification(s):

4. How many years have you taught in public schools?

5. Please circle your highest level of education
a. Bachelor's degree
b. Bachelor's degree plus graduate credits
c. Master's degree
d. Master's degree plus graduate credits beyond a master's degree
e. Doctoral degree

6. Please list the major areas of study of your degree(s)

7. Please indicate the number of credits in special education you have completed:

8. Please give the number of students with disabilities included in your classroom.

9. Please provide your e-mail address 


\section{Appendix D}

CRIME Process Forms (Prater, 2003, p. 60)

Step 1: Evaluate the general education classroom.

\begin{tabular}{ll}
\hline $\begin{array}{l}\text { CRIME } \\
\text { category }\end{array}$ & Included in the category \\
\hline Curriculum & $\begin{array}{l}\text { Content, difficulty, and standards. All students are working toward the } \\
\text { state curriculum standards. The level of difficulty is on grade level. } \\
\text { Students are accountable for meeting the standards to graduate in } 2 \\
\text { years. }-10^{\text {th }} \text { Grade. }\end{array}$ \\
\hline Rules & $\begin{array}{l}\text { Implicit and explicit rules. There are three written rules: No talking, } \\
\text { show respect for others, do your own work. }\end{array}$ \\
\hline Instruction & $\begin{array}{l}\text { Teaching style, individual and group work, pace, teacher and student } \\
\text { directed. I vary my instructional style. Lecture, class discussion, }\end{array}$ \\
& $\begin{array}{l}\text { independent work, and group work. Students complete end of chapter } \\
\text { questions. }\end{array}$ \\
\hline Materials & $\begin{array}{l}\text { Textbooks, trade books, tests, homework, equipment, supplies. Texts } \\
\text { and packets. The text is an essay text. End of chapter questions which } \\
\text { must be typed. Typical school supplies. }\end{array}$ \\
\hline Environment & $\begin{array}{l}\text { Furniture, seating, space, doors, window, barriers. The desks are in rows. } \\
\text { The students are seated close to their classmates. A large window faces } \\
\text { the football field. The class is crowded. }\end{array}$ \\
\hline
\end{tabular}

Step 2: Evaluate the student's strengths and limitations.

\begin{tabular}{lll}
\hline Skills/preferences & Strengths & Limitations \\
\hline Academic skills & $\begin{array}{l}\text { She comprehends verbal } \\
\text { instruction and discussion. }\end{array}$ & $\begin{array}{l}\text { Poor writing skills. } \\
\text { Sloppy work. }\end{array}$ \\
& $\begin{array}{l}\text { Good verbal expression. } \\
\text { Strong auditory memory. }\end{array}$ & \\
& Understands concepts. & \\
\hline Learning preferences & Enjoys class discussions. & $\begin{array}{l}\text { Doesn't like independent work. } \\
\text { Likes working in groups. }\end{array}$ \\
& Gets along with other & $\begin{array}{l}\text { Forgets homework and becomes } \\
\text { frustrated }\end{array}$ \\
& students. & Discouraged by low test scores. \\
\hline
\end{tabular}


Step 3: Compare the classroom practices with the student's strengths and limitations.

\begin{tabular}{|c|c|c|c|c|}
\hline Category & $\begin{array}{l}\text { General } \\
\text { education } \\
\text { classroom }\end{array}$ & $\begin{array}{l}\text { Facilitates } \\
\text { learning }\end{array}$ & $\begin{array}{l}\text { Neutral } \\
\text { for student }\end{array}$ & $\begin{array}{l}\text { Barriers for } \\
\text { learning }\end{array}$ \\
\hline Curriculum & $\begin{array}{l}\text { State } \\
\text { curriculum. }\end{array}$ & $\begin{array}{l}\text { Conceptual } \\
\text { Understanding. } \\
\text { Verbal expression. }\end{array}$ & & $\begin{array}{l}\text { Reading } \\
\text { Writing }\end{array}$ \\
\hline Rules & $\begin{array}{l}\text { Complete } \\
\text { class work. } \\
\text { Arrive on } \\
\text { time. } \\
\text { Turn in } \\
\text { homework. }\end{array}$ & & $X$ & Forgetful. \\
\hline Instruction & $\begin{array}{l}\text { Lecture. } \\
\text { Independent } \\
\text { work. } \\
\text { Group work. } \\
\text { Questions. } \\
\text { Written tests. }\end{array}$ & $\begin{array}{l}\text { Auditory skills. } \\
\text { Gets along with } \\
\text { others. } \\
\text { Conceptual } \\
\text { understanding. }\end{array}$ & $X$ & $\begin{array}{l}\text { Note taking. } \\
\text { Reading, writing. } \\
\text { Reading, writing. } \\
\text { Reading, writing. }\end{array}$ \\
\hline Materials & $\begin{array}{l}\text { Essay tests. } \\
\text { Written } \\
\text { projects. } \\
\text { Computer } \\
\text { assignments. } \\
\text { Class } \\
\text { materials. }\end{array}$ & $\begin{array}{l}\text { Concepts. } \\
\text { Concepts. } \\
\text { Computer skills. }\end{array}$ & $X$ & $\begin{array}{l}\text { Reading, writing. } \\
\text { Writing. }\end{array}$ \\
\hline Environment & $\begin{array}{l}\text { Crowded } \\
\text { Class. } \\
\text { Windows } \\
\text { outside. }\end{array}$ & & $X$ & $\begin{array}{l}\text { Gets distracted } \\
\text { watching the P.E. } \\
\text { classes. }\end{array}$ \\
\hline
\end{tabular}


Step 4: Plan adaptations and accommodations that facilitate learning and minimize the effects of learning barriers.

\begin{tabular}{|c|c|c|c|}
\hline Adaptations and goals & $\begin{array}{l}\text { Teaches a } \\
\text { new skill }\end{array}$ & $\begin{array}{l}\text { Facilitates } \\
\text { learning }\end{array}$ & $\begin{array}{l}\text { Reduces a } \\
\text { barrier }\end{array}$ \\
\hline $\begin{array}{l}\text { General education teacher will: } \\
\text { Arrange for the student to tape record } \\
\text { the lectures. }\end{array}$ & & $X$ & $\mathrm{X}$ \\
\hline $\begin{array}{l}\text { Allow the student to use a computer to } \\
\text { take weekly exams. }\end{array}$ & & $X$ & $\mathrm{X}$ \\
\hline $\begin{array}{l}\text { Modify the term project into a } \\
\text { cooperative learning project. }\end{array}$ & & $X$ & $X$ \\
\hline Special education teacher will: & & & \\
\hline Teach note-taking skills. & $\mathrm{X}$ & & \\
\hline $\begin{array}{l}\text { Create a self-monitoring sheet for } \\
\text { homework completion. }\end{array}$ & $\mathrm{X}$ & & \\
\hline
\end{tabular}




\section{Appendix E}

\section{Sample Transcription}

General Education Teacher - Pair 2

In as much detail as possible, describe your experience completing the CRIME process with the special education teacher. As you describe this process, give as much detail as possible about what you said, and what she said, and your thoughts and reactions to what was discussed.

I pretty much had this filled out when we met. We discussed and she added to, and she added to the special education teacher part. I pretty much had the rest of this filled out. Ok. If you could go through each part and describe in as much detail as possible what that was like for you to do.

In the curriculum area, the content that we go through is pretty much grade level difficulty and the students work toward their state curriculum standards on a daily basis in all areas. The rules, and I have them listed up here on a chart at the front of the room, follow directions, keep hands, feet and objects to yourselves, no name callings, put downs or teasing, and that tends to be a problem for this boy. Putting . . . Not any of his peers in the classroom, but those that he works with in the resource area he puts some down and teases occasionally and we've talked with him about that on occasion. What was your discussion about the rules? What was your discussion with the special education teacher?

She has told me in the past that she's had a problem, especially with one boy, calling him names and putting him down a little bit. That surprises me because he's one that hates having that done to him. Yet he turns around and does that to someone else. 
So you're not seeing that behavior.

I'm not seeing that in my regular classroom. No. Respect self, others and all property, and homework completed on time. That's an area of concern.

Did you both note that?

We both noted that. Instructional styles, I have varied instructional styles. I do very little lecturing. At this level I don't think the kids can handle a whole lot of lecturing. I do a lot of in class discussion and give them independent work along with group work. Materials we use in this classroom are resource materials to complete packets. We don't have a lot of textbooks. Math texts we do use. We do have a history text, but you can see that it's on the shelves and it's more of a resource to help complete work. They use typical school supplies and they do many written projects. The environment of our room. You can tell, our room doesn't have a window. ... 


\section{Appendix F}

Coding Categories--CRIME, Process, and Evaluation

Process - Normal Type

$\underline{\text { CRIME - Underlined }}$

\section{Evaluation - Lucinda Handwriting font}

General education - Pair 4

In as much detail as possible, describe your experience completing the CRIME process with the special education teacher.

You don't have questions?

This is open ended.

She went ahead and did most of the writing to begin with. I took things and kind of tweaked them so that they fit my situation here in the classroom.

Did you do that after?

After, yes. Everything we talked about we agreed on, but then I kindof modified a couple of things that I thought might help him better in my classroom situation. Because he has a larger group of people to deal with in my classroom.

Many of our rules were the same and so I felt that the rules were going to

be consistent.

Like for example?

$\underline{\text { Raising your hands to talk. Sitting in the ready position to learn. Being respectful to }}$ others. Not disturbing others during class time. Those were things that were the same. Our instruction style I found was quite a bit alike. 
Appendix G

CRIME Category Condensed Statements

General education teachers

\section{CLASSROOM}

Curriculum

Team leader worked with the special education teacher. The special education teacher is also working on curriculum.

Is working on math skills at a $3^{\text {rd }}$ grade level.

Grade level curriculum.

Teaches character traits units.

Math investigations is the math curriculum.

Uses district printed information for phonics.

Teaches science units.

Does skip counting and multiplication.

\section{Rules}

Respect is expected in $6^{\text {th }}$ grade and they are strict in the hallways.

Expects homework to be completed.

Teaches rules at the beginning of the year. Goes over general

guidelines for the school.

Practices and reviews respect.

Rules are listed in the classroom.

Rules are respect self, others and property, and complete

homework on time.

Both classroom rules were very close to what each was expecting. Has visual behavior cards for the student so the student can visually see behavior.

Many of their rules were the same.
Special education teachers

\section{CLASSROOM \\ Curriculum}

Worked on skip counting in the special education class. Taught factoring.

Goes by state core in reading.

Is working on the student's comprehension and writing skills.

Teaches the $1^{\text {st }}$ grade curriculum.

Teaches close to the state curriculum.

The general education teacher works closely with state curriculum.

Tries to provide access to the general education curriculum.

Teacher starts out with the standards and task analyzes to find what the student missed.

Rules

The rule is respect.

The whole school is learning respect.

Rules are to keep busy and show respect.

The teacher doesn't like anyone else in charge and wants students to keep busy.

The general education teacher reinforces what the special education teacher needs reinforced for behavior.

Rules are posted. The class generates rules at the beginning of the school year, and the teacher teaches the rules.

Provides choices when the students misbehave.

An implied rule is the homework routine.

The teacher has 5 class rules. 


\section{Appendix $\mathrm{H}$}

Code Definitions

\section{CRIME QUOTATIONS}

CRIME: CRIME quotations are quotations about elements of the CRIME process which are curriculum, rules, instruction, environment, the student's strengths and limitations, and adaptations and accommodations.

\section{CRIME Elements}

Curriculum: The content of what the teacher teaches. For example: state curriculum, investigations, balanced literacy, grade level, etc., and what the curriculum includes (skip counting, factoring, comprehension, writing, science, character units, etc.).

Rules: Classroom rules for either the special education class or the general education class. Rules include: respect others, hands to self, complete homework, keep busy, good habits, etc.

Instruction: How the teacher presents information. For example: Lecture, small group, large group, individual instruction, hand on centers.

Materials: Materials the teacher uses, or materials that are available for the students to use. Materials include: packets, books, paper, pencils, manipulatives, etc.

Environment: Descriptions of either the general education classroom environment or the special education classroom. Quotations include how the room is arranged, windows in the classroom, whether the room is crowded, the number of students in the classroom, and the noise level in the classroom. 


\section{Student}

General: Neutral general comments about the student. For example: The student has a hearing aide. The student is in the special education class for two hours a day.

Strengths: Statements that are positive about the student. For example: The student is motivated, likes to learn, gets along well with peers, has good auditory memory, can contribute in class, is verbal, likes to work with other students, has friends, loves books, etc.

Limitations: Statements that reflect skill deficits or problems with the student. For example: The student has processing problems. The student has difficulty reading and writing. The student's behavior has cropped up in the special education classroom. The student puts down other students. The student gets frustrated in class.

Adaptations: Statements about what the teachers are doing, or plan to do to make accommodations and adaptations for the student. Adaptations include reducing work, using computers and microphones, teaching social skills, teaching note taking skills, teaching organization, moving seats, checking the student's work, etc. Quotations that are categorized as CRIME quotations will state CRIME. The subcategories of the CRIME category are listed after CRIME. For example: CRIME/student/strengths indicates that the quotation is a CRIME category quotation about the student's strengths.

\section{PROCESS QUOTATIONS}

PROCESS: Process quotations are quotations about what the teachers did as they completed the CRIME steps. Process quotations include: how the teachers completed the process, what each contributed, what they did and did not do, and what they thought. 
Mechanics: Any quotations that reflect what the teachers did. Mechanics includes: we found, we talked, we saw, we realized, we noted, we filled out the page, we met, we used the example, we added, went over, we had consensus, we did not have disagreements, and any statement about how long they worked.

Special Education: Statements that reflect something the special education teacher did or did not contribute to the process. For example: The special education did not write it down, the special education teacher contributed that the student's work was sloppy, etc. Special education quotations also include statements where the special education teacher describes what he/she discovered or learned such as I saw, I learned, etc.

General Education: Statement that reflect something the general education teacher did or did not contribute to the process. For example: She didn't discuss her rules. She reminded the special education teacher that the student is willing to please. General education quotations also include statements where the special education teacher describes what he/she discovered or learned such as I saw, I learned, etc.

Thought: A statement the teacher describes as a thought, or a statement that describes thinking or remembering such as: I thought through the different pieces, I re-remembered how much variation there is in my class, and I thought a computer would help the student.

\section{EVALUATION QUOTATIONS}

EVALUATION: Quotations that are statements the teachers made that are judgments, evaluations about themselves, about their classroom or the other teacher's classroom, about the other teacher, about the student, about the process of working together, or about the CRIME model. 
Perceptions of self/opinions: Expressions of their opinions, expectations, and realizations about themselves. Perception quotations include statements about what they are or are not doing, statements that reflect judgment about themselves or their work such as it was hard, this is easy, etc.; and includes expressions of frustration such as: it was frustrating that those weren't her concerns.

Classroom(s): Statements that reflect opinions and evaluations of their classroom and/or the other teacher's classroom such as: our rules were consistent, the classroom is nonthreatening for the student, the classroom is positive, etc.

Other Teacher(s): Statements that reflect what the teacher thinks about the other teacher, what he/she wants from the other teacher, what the teacher thought the other teacher thought, what the teacher thinks the other teacher can and cannot do, and judgments about the other teacher. For example: she's frustrated, that wasn't her concern, she doesn't know what I do, her biggest problem is the student's attention, it was good that she saw the student had strengths, etc.

Student(s): Statements that reflect what the teacher thinks about the student, the student's ability; what the teacher wants for the student, and what the teacher thinks the student thinks about something. For example: The student will never be a normal child, reading is hard for the student, the student needs to learn social skills, the student needs to learn to take notes, etc.

Process: Statements that reflect the teachers' evaluation of the process of working together, and their descriptions of challenges, barriers, and frustrations they encountered completing the process. For example: It was beneficial, I thought it was great, I liked it, and time was the biggest barrier. 
CRIME model: Statements about specific elements of the CRIME process such as reference to particular elements, pages, and terms, or to the model itself. For example, I liked the rules. I didn't understand facilitators, I thought page 3 was redundant, etc. 
Appendix I

General Education Teacher--Pair 5 Coded Interview

\begin{tabular}{|c|c|}
\hline Interview - General education teacher Pair \#5 & Coding \\
\hline $\begin{array}{l}\text { In as much detail as possible, describe what your experience was completing this process with } D_{-} \text {, } \\
\text { who did what, who contributed what, and what you said or thought. }\end{array}$ & \\
\hline $\begin{array}{l}\text { We worked together during lunch time. We both told our thoughts and tried to put those, both of our } \\
\text { thought on the paper, specific things that helped. }\end{array}$ & Process/mechanics \\
\hline $\begin{array}{l}\text { Because I knew more about what he was doing with M_ during that reading/writing time that she's } \\
\text { pulled out. The skills that he's teaching her. }\end{array}$ & Evaluation/other teacher \\
\hline $\begin{array}{l}\text { And I was looking at the different ways that we adapted for her, or had that facilitator for her or reduced } \\
\text { the barrier. }\end{array}$ & Process/gen. ed. \\
\hline $\begin{array}{l}\text { It was interesting to think about it that way. It was interesting to have the barrier thoughts, oh this is a } \\
\text { barrier towards her education, how can we remove that barrier. In my mind, I saw that very very clearly } \\
\text { the way it was described. It also helped us to communicate about things that we felt, goals that M- } \\
\text { needs to work toward, and where everything is going in her special education classes and in her regular } \\
\text { classes so it helps us zero in on those things. } \\
\text { Can you give me an example? }\end{array}$ & Evaluation/process \\
\hline We recognized that her writing is extremely difficult for her. & Process/mechanics \\
\hline She can say something but in order for her to communicate it in writing it is very very difficult. & Evaluation/student \\
\hline $\begin{array}{l}\text { So, one of our goals is for } M \text { to answer things, not orally, but in written form that she can handle, the } \\
\text { amount of writing that she can handle. So say for example a math assignment where she has to explain } \\
\text { her thinking, as I'm working with her I can say how can you explain that. Instead of giving a long } \\
\text { explanation, like maybe some of the students. One sentence. Explain why you know this is a right } \\
\text { triangle. And she does have a hard time with her intellectual ability with those assignments. But there are } \\
\text { many ways that she has been able to participate, and that's something that she's been able to work on her } \\
\text { writing or her reading or her other skills that she needs, and we talked about that. }\end{array}$ & $\begin{array}{l}\text { CRIME/student/limitations } \\
\text { \& adaptations }\end{array}$ \\
\hline
\end{tabular}


Appendix J

Collaboration Experience and Collaboration Defined

\begin{tabular}{|c|c|c|c|c|c|}
\hline $\begin{array}{l}\text { All four } \\
\text { steps }\end{array}$ & Common philosophy & Common Goals & $\begin{array}{l}\text { Discussed differences/ } \\
\text { differences surfaced }\end{array}$ & Agree on Problem & $\begin{array}{l}\text { Equality in } \\
\text { interaction }\end{array}$ \\
\hline $1-\mathrm{No}$ & $\begin{array}{l}\text { No } \\
\text { General education: } \\
\text { Normalize the student. } \\
\text { Special education: } \\
\text { Student was disabled } \\
\text { and needed structure } \\
\text { and support. }\end{array}$ & $\begin{array}{l}\text { No } \\
\text { General education: To } \\
\text { normalize the student } \\
\text { and get the student } \\
\text { ready for junior high } \\
\text { school. } \\
\text { Special education: To } \\
\text { move the student } \\
\text { forward and to provide } \\
\text { support. }\end{array}$ & $\begin{array}{l}\text { No } \\
\text { Classroom } \\
\text { environment. The } \\
\text { special education } \\
\text { teacher did not think } \\
\text { the environment was } \\
\text { neutral for student. }\end{array}$ & $\begin{array}{l}\text { No } \\
\text { General education: } \\
\text { Thought the problems } \\
\text { were the student chose } \\
\text { not to focus and was } \\
\text { unorganized. } \\
\text { Special education: } \\
\text { Believed the student } \\
\text { had a processing } \\
\text { problem that impacted } \\
\text { all areas of the } \\
\text { student's life }\end{array}$ & $\begin{array}{l}\text { Dominated by } \\
\text { the general } \\
\text { education } \\
\text { teacher. }\end{array}$ \\
\hline 2 - Yes & $\begin{array}{l}\text { Yes } \\
\text { General education: The } \\
\text { student wasn't } \\
\text { performing up to } \\
\text { capability and was } \\
\text { lazy--normalize. } \\
\text { Special education: The } \\
\text { student had a } \\
\text { processing problems } \\
\text { but the real problem } \\
\text { was the student was } \\
\text { lazy--normalize. }\end{array}$ & $\begin{array}{l}\text { Yes } \\
\text { Both wanted the } \\
\text { student to complete } \\
\text { grade level work, and } \\
\text { to acquire skills he } \\
\text { would need for life. }\end{array}$ & $\begin{array}{l}\text { No } \\
\text { The special education } \\
\text { teacher didn't agree } \\
\text { with the general } \\
\text { education teacher's } \\
\text { assessment of the } \\
\text { student's learning } \\
\text { preferences. } \\
\text { Yes } \\
\text { They discussed their } \\
\text { experiences with the } \\
\text { student and decided } \\
\text { different perspectives } \\
\text { were possible. }\end{array}$ & $\begin{array}{l}\text { Yes } \\
\text { General education: } \\
\text { Student was not } \\
\text { completing class work } \\
\text { and was behaving } \\
\text { inappropriately in the } \\
\text { special education class. } \\
\text { Special education: } \\
\text { Student was not } \\
\text { completing class work } \\
\text { and was behaving } \\
\text { inappropriately in the } \\
\text { special education class. }\end{array}$ & $\begin{array}{l}\text { Dominated by } \\
\text { the general } \\
\text { education } \\
\text { teacher }\end{array}$ \\
\hline
\end{tabular}




\begin{tabular}{|c|c|c|c|c|c|}
\hline $3-$ Yes & $\begin{array}{l}\text { Yes } \\
\text { General education: } \\
\text { Wanted the student } \\
\text { normalized, but } \\
\text { realized it would not } \\
\text { happen and the student } \\
\text { needed specialized help } \\
\text { and accommodations. } \\
\text { Special education: } \\
\text { Student was disabled } \\
\text { and needed specialized } \\
\text { help. }\end{array}$ & $\begin{array}{l}\text { Yes } \\
\text { Agreed to address the } \\
\text { general education } \\
\text { teacher's problem with } \\
\text { the student. }\end{array}$ & $\begin{array}{l}\text { No } \\
\text { The special education } \\
\text { teacher thought the } \\
\text { general education } \\
\text { teacher's style of } \\
\text { instruction was a } \\
\text { problem for the student } \\
\text { Yes } \\
\text { They discussed } \\
\text { different perspectives } \\
\text { of the student's } \\
\text { strengths. }\end{array}$ & $\begin{array}{l}\text { Yes } \\
\text { General education: She } \\
\text { needed help with the } \\
\text { student. } \\
\text { Special education: } \\
\text { Believed the general } \\
\text { education teacher } \\
\text { needed help. }\end{array}$ & $\begin{array}{l}\text { Dominated by } \\
\text { the special } \\
\text { education } \\
\text { teacher }\end{array}$ \\
\hline 4 - No & $\begin{array}{l}\text { No } \\
\text { General education: } \\
\text { Student was not like } \\
\text { other children but } \\
\text { expectations for the } \\
\text { student should be the } \\
\text { same as for other } \\
\text { children. } \\
\text { Special education: } \\
\text { Student was not like } \\
\text { other children and } \\
\text { should not be expected } \\
\text { to perform the same. } \\
\text { The student was not } \\
\text { capable. }\end{array}$ & $\begin{array}{l}\text { No } \\
\text { General education: To } \\
\text { have the student } \\
\text { complete his work. } \\
\text { Special education: To } \\
\text { provide } \\
\text { accommodations for } \\
\text { the student. }\end{array}$ & $\begin{array}{l}\text { No } \\
\text { Did not discuss class } \\
\text { rule differences. The } \\
\text { special education } \\
\text { teacher did not think } \\
\text { the general education } \\
\text { teacher's expectations } \\
\text { for students following } \\
\text { rules were reasonable } \\
\text { for the student. }\end{array}$ & $\begin{array}{l}\text { Yes/No } \\
\text { Agreed that the } \\
\text { student's behavior was } \\
\text { a problem } \\
\text { General education: } \\
\text { Wanted the student to } \\
\text { complete his class } \\
\text { work. } \\
\text { Special education: } \\
\text { Thought the student } \\
\text { needed classroom } \\
\text { support, and that his } \\
\text { workload should be } \\
\text { reduced. }\end{array}$ & $\begin{array}{l}\text { Dominated by } \\
\text { the special } \\
\text { education } \\
\text { teacher }\end{array}$ \\
\hline 5 -Yes & $\begin{array}{l}\text { Yes } \\
\text { General education: } \\
\text { Believed the student } \\
\text { had limitations and }\end{array}$ & $\begin{array}{l}\text { Yes } \\
\text { Both teachers wanted } \\
\text { to help the student } \\
\text { improve her basic }\end{array}$ & $\begin{array}{l}\text { Yes } \\
\text { They discussed their } \\
\text { different perceptions of } \\
\text { how to achieve goals }\end{array}$ & $\begin{array}{l}\text { Yes } \\
\text { General education: } \\
\text { Student had a problem } \\
\text { working with other }\end{array}$ & $\begin{array}{l}\text { Dominated by } \\
\text { the general } \\
\text { education } \\
\text { teacher }\end{array}$ \\
\hline
\end{tabular}




\begin{tabular}{|c|c|c|c|c|c|}
\hline & $\begin{array}{l}\text { needed classroom } \\
\text { support. } \\
\text { Special education: } \\
\text { Believed the student } \\
\text { had limitations and } \\
\text { needed classroom } \\
\text { support. }\end{array}$ & skills. & $\begin{array}{l}\text { for the student. The } \\
\text { special education } \\
\text { teacher told the general } \\
\text { education teacher that } \\
\text { he couldn't help the } \\
\text { student learn to write } \\
\text { paragraphs until } \\
\text { student learned to write } \\
\text { sentences. }\end{array}$ & $\begin{array}{l}\text { students, and student } \\
\text { needed to improve her } \\
\text { reading writing, and } \\
\text { comprehension skills. } \\
\text { Special education: } \\
\text { Student needed to } \\
\text { improve reading and } \\
\text { writing, and } \\
\text { comprehension skills. }\end{array}$ & \\
\hline $6-$ Yes & $\begin{array}{l}\text { Yes } \\
\text { General education: } \\
\text { Expectations for } \\
\text { students with } \\
\text { disabilities should be } \\
\text { the same as for other } \\
\text { students. Students with } \\
\text { disabilities need } \\
\text { environmental support. } \\
\text { Special education: } \\
\text { Students with } \\
\text { disabilities can learn. } \\
\text { Students with } \\
\text { disabilities have } \\
\text { limitations and need } \\
\text { environmental support. }\end{array}$ & $\begin{array}{l}\text { Yes } \\
\text { Both teachers wanted } \\
\text { to have the student } \\
\text { continue to maintain } \\
\text { grade level } \\
\text { performance and to } \\
\text { improve her social } \\
\text { skills. }\end{array}$ & $\begin{array}{l}\text { Yes } \\
\text { They discussed their } \\
\text { different perceptions of } \\
\text { implicit rules that } \\
\text { needed to be taught to } \\
\text { student. }\end{array}$ & $\begin{array}{l}\text { Yes } \\
\text { General education: } \\
\text { Student was } \\
\text { experiencing difficulty } \\
\text { with the math } \\
\text { curriculum and also } \\
\text { needed to learn better } \\
\text { social skills. } \\
\text { Special education: The } \\
\text { student was } \\
\text { experiencing difficulty } \\
\text { with the math } \\
\text { curriculum and also } \\
\text { needed to learn better } \\
\text { social skills. }\end{array}$ & $\begin{array}{l}\text { Dominated by } \\
\text { the special } \\
\text { education } \\
\text { teacher }\end{array}$ \\
\hline
\end{tabular}




\section{Appendix K}

Summary of the Experience

Nature of the experience. The teachers analyzed their classrooms and compared their classroom practices and environments with their students' learning profiles. As the teachers completed each step of the CRIME process, they shared, discussed, and analyzed information about themselves, the other teacher, and the student. The process of analysis was complex. As the teachers shared, discussed, and analyzed information they filtered it through their own perspectives and philosophies. Depending on the information discussed and their analysis of the information, the teachers agreed with each other and moved through the process, or they encountered differences that required discussion. Some of the pairs of teachers discussed their differences and achieved a common understanding related to their differences, and then jointly defined a problem to address. After the teachers defined a problem to address, they jointly assumed responsibility for addressing the problem. Other pairs of teachers avoided discussing their differences, or discussed their differences and did not resolve them, which impacted their collaboration experience in that they did not jointly define a problem to address, and did not complete the final step of the CRIME process together.

Collaboration defined. All of teachers who completed all four steps of the CRIME process (a) voluntarily agreed to collaborate, (b) contributed in different ways consistent with their knowledge, expertise, and experience, (c) discussed and defined a problem to address, and (d) expressed commitment for addressing the problem. The difference between the pairs of teachers who completed the process together and those 
who did not was the teachers who did not complete the process did not jointly define a problem, and they did not plan accommodations and adaptations together.

Perceptions of the CRIME Model. All of the teachers stated that completing the CRIME process was beneficial. They explained that the process was beneficial in terms of evaluating their students' needs, evaluating their efforts in meeting their students' needs, and having a focused in-depth discussion with the special or general education teacher. Although the teachers reported that the process was beneficial, all of the teachers did not complete the process together. When asked their perceptions of the CRIME model, some teachers stated that they thought all of the steps were necessary for planning accommodations and adaptations for their students, and other teachers stated that they thought some of the steps were redundant and not necessary. Specifically, they thought steps 3 and 4 were redundant. Also, some of the teachers reported that they did not understand the term facilitator and were uncertain how to complete the facilitator column of step 3. Eight out of the twelve teachers reported implementing at least one accommodation or adaptation for their student. All of the teachers said that finding time to complete the CRIME process was a barrier. The teachers spent between 30 minutes and one hour completing the process. 
Appendix L

CRIME Training Checklist

Check the box if the researcher completed the steps as described.

The researcher gave an overview of the CRIME process.

Step One - The researcher explained step one: Evaluate the general education classroom. The researcher discussed each element of this step as illustrated on the completed sample.

Step Two - The researcher explained step two: Record descriptions of the student's academic and behavioral strengths and limitations. The researcher discussed each element of this step as illustrated on the completed sample.

Step Three - The researcher explained step three: Compare the classroom practices with the student's profile to identify learning facilitators and limiters.

The researcher discussed each element of this step as illustrated on the complete sample.

Step Four - The researcher explained step four: Plan classroom adaptations and accommodations to support learning. The researcher discussed each element of this step as illustrated on the completed sample.

The researcher questioned for understanding, and allowed opportunity for the teachers to ask questions and make comments about the process.

Training completed on

Teacher's name Teacher's signature 


\section{Appendix M}

Teachers' Comments About Their Students

\begin{tabular}{|c|c|c|}
\hline Topic discussed & General education & Special education \\
\hline General comments & $\begin{array}{l}\text { Student has a hearing aide. } \\
\text { He sits in the center of the classroom. } \\
\text { Student was in full resource last year and is not } \\
\text { keeping up like they'd like. } \\
\text { Has other students with the same problem. } \\
\text { Is in special education classroom } 1 \text { hour/day. }\end{array}$ & $\begin{array}{l}\text { Student's mother is working on handwriting. } \\
\text { Students sits up front on the end of the first row. } \\
\text { He spends most of the day in the general education } \\
\text { class. } \\
\text { Student is in special education for math, and just } \\
\text { started for reading instruction. } \\
\text { There is an FM system for the student. } \\
\text { Student is placed under the loud speaker. }\end{array}$ \\
\hline Student's strengths & $\begin{array}{l}\text { Pair } 1 \\
\text { Student does better with personal rapport with the } \\
\text { teacher. } \\
\text { When student chooses to be benefited she is. } \\
\text { Can stick with a task when motivated. } \\
\text { Works hard for verbal feedback. } \\
\text { Is positively stubborn. She will keep going when } \\
\text { she chooses to be benefited. }\end{array}$ & $\begin{array}{l}\text { Pair } 1 \\
\text { Learning preference is explicit one-to one } \\
\text { instruction. } \\
\text { Works better in smaller groups. } \\
\text { Wants to please her teachers and do well. } \\
\text { Does better in small groups. } \\
\text { When student can see how things break down, she } \\
\text { can learn. } \\
\text { Is good about brining her folder back. } \\
\text { Has a positive attitude. }\end{array}$ \\
\hline & $\begin{array}{l}\text { Pair } 2 \\
\text { Is an auditory learner and student is better with } \\
\text { auditory than with reading. } \\
\text { Good with his hands. } \\
\text { Physical labor is a strength. } \\
\text { Writes legibly. }\end{array}$ & $\begin{array}{l}\text { Pair } 2 \\
\text { Can decode well. } \\
\text { Is more manual than academic. } \\
\text { Can comprehend if he paid more attention. }\end{array}$ \\
\hline
\end{tabular}


Likes working in groups.

Will take instructions from a group member.

Reads fairly well but not on grade level.

Copying is ok.

Pair 3

Reading a book is a reward for the student.

Nice handwriting and can copy.

Can read CVC words and knows letters and sounds.

Can count.

Student can do thinking position without being prompted.

Loves the computer.

Loves books and visual things.

Pair 4

Verbally expresses himself well and is very auditory.

Likes to work with other students.

Can depend on other students when things get difficult for him.

Other students don't completely shun him and he has friends.

\section{Pair 5}

Student had a strategy to find out how to spell a word she needed to write.

Does better on individual work than group work. Tools such as calculators are helpful for the student.
Pair 3

He can follow one step prompts.

Student's projects are better than other students'.

Coloring is awesome.

Knows the sounds of letters and can blend CVC words.

Student is a visual learner.

Will do anything for a reward.

Loves computers and books.

Loves looking at books.

Pair 4

Auditory memory is good.

Verbal expression is good.

Student participates in the general education class unless the material becomes too difficult.

Student contributed in the special education class.

Pair 5

Student is motivated to learn and wants to please.

Has good family support.

Verbal IQ is 76 and performance is 97.

Likes to work individually more than in a group.

Will follow a peer model. 
Perfectionism is a strength and a barrier.

\section{Pair 6}

Comprehends verbal instructions.

Enjoys class discussion.

Likes working in groups.

Follows directions with instructions.

Memorizes well.

\section{Student's}

Limitations

Pair 1

Can't break down problems, they are overwhelming for her.

Can be stubborn and close minded.

If she feels she can't be successful, she won't open her mind to the work.

Can't break down information enough for her to realize organization will help her in the future.

Closes to her mom.
Sometimes student's expectations are real and student accepts personal limitations.

Pair 6

Knows material inside out.

Great memorization skills.

Likes to be with her peers.

Likes being included in the general education class.

Pair 1

Doesn't know her times tables.

Listening is a limitation.

Barrier is reason and logic, and listening and remembering steps.

Student can't find materials and organization is a barrier.

Work is sloppy.

Can't break things down.

Writing and organization are barriers.

Can't read anything she writes. It's a real barrier for her for doing homework.

Has a hard time focusing when a lot is going on.

Has conceptual limitations and has difficulty

figuring out steps.

Doesn't always comprehend what she reads.

Reading skills are lower.

Student can't find anything on own.

Student is one of the general education teacher's lower reading students. 


\section{Pair 2}

Independent studies is a limitation.

Doesn't take homework home.

Procrastinates and has no desire to succeed academically. He waits until the last minute. Poor attitude about what he's asked to do.

Writing and math are barriers.

Puts other students down in resource class.

Struggles with comprehension and writing.

Writing and math don't always make sense to the student.

Can tune out lectures.

Has difficulty expressing his thoughts.

Student has limitations.

Barriers are listening and note taking.

Student can write notes if he copies what's

written on the board.

Has difficulty with tests.

Doesn't study.

Gets lost in class.

Pair 3

Limitation is reading--mostly limited in reading comprehension.

Slow processing any kind of class discussion.

Hard time answering questions or following class discussions.

Aide is with the student all day.

Barrier is the student's independence.

Student is very distracted by things in the classroom.

\section{Pair 2}

Student won't study at home.

Difficult for the student to be independent.

Student has a processing problem.

Needs help with reading, writing and math.

Completing homework on time is a problem for the student.

Writing is a barrier on written tests and basic tests.

Writes one sentence on a whole page.

Comprehension is below grade level.

Gets frustrated in the general education classroom.

Is lazy and forgetful completing homework.

Has problems taking notes.

Gets distracted in class.

\section{Pair 3}

Not an auditory learner.

Limitations are listening skills, attention, and

following directions.

Student is behind on curriculum.

Student is not an independent learner.

Always needs a prompt from the aide.

Limitation is listening, following directions, and attention.

Blends words but doesn't comprehend. 
Noise in the classroom can be distracting for the student. He'll make noise.

Has a hard time answering questions and following discussions.

Aide prompts him.

Attention is limited.

Giggles in class.

\section{Pair 4}

Student whistles to get the teacher's attention. Student forgets to take home homework.

Tries to get the attention of girls who sit by him.

Barriers are math concepts and writing.

In the morning the student is great, but by afternoon, the student is tired and has a harder time.

Takes student twice as long to copy overhead information.

\section{Pair 5}

Writing is difficult for the student.

Because of the student's intellectual ability, the student has a hard time with assignments.

Student doesn't like to work in groups and wants to do work on her own and is not open to someone telling her what to do.

\section{Not listening is a barrier.}

Student is not independent.

Makes noise and engages in repetitive behaviors.

Environment creates distractions for the student.

\section{Pair 4}

Student has mildly offensive behaviors and makes noises, taps, and is off task.

Fine motor skills are not well developed.

Writing is difficult for the student

Has trouble pronouncing some words. Has speech therapy.

Can't transfer information from the board. It takes him double time to complete work.

He avoids taking homework home and expects to be excused from assignments.

Student doesn't pick up that he shouldn't bother the girl next to him.

Student was very chatty in class.

Student has a problem picking up on social cues.

\section{Pair 5}

Hard for the student to follow what's going on in a group and gets lost.

Student is slow in copying notes and the task is nearly impossible for the student.

Student is a perfectionist. She traces numbers and letters several times. 
Student does not read on a $5^{\text {th }}$ grade level.

Student is a perfectionist

Reading skills are a barrier for the student.

\section{Pair 6}

Not able to verbalize quickly or fluently.

Not a strong auditory learner.

Doesn't like independent work.

Forgets homework.

Is absent quite a bit.

Doesn't get concepts.

Has a hard time finding groups if the teacher doesn't assigned a group.

Takes longer to complete work and does better if she has fewer things to focus on.

On independent student-directed work she gets stuck.
She makes sure letters are perfect, but misses

important information in class.

Student gets snippy and wants things her way.

Difficult in general education class for the student

to accept peer feedback.

Student follows directions to the extreme.

\section{Pair 6}

Has a hard time comprehending grade level materials and struggles with word problems. Doesn't understand contributing to a group.

Is innocent and doesn't take offense, but doesn't get it.

Investigations is a barrier for learning. 